\title{
Nothing But Gold. Complexities in Terms of Non-difference and Identity
}

\author{
Part 1. Coreferential Puzzles
}

\author{
Alberto Anrò ${ }^{1}$ iD
}

Accepted: 4 January 2021 / Published online: 27 February 2021

(C) The Author(s) 2021

\begin{abstract}
Beginning from some passages by Vācaspati Miśra and Bhāskararāya Makhin discussing the relationship between a crown and the gold of which it is made, this paper investigates the complex underlying connections among difference, non-difference, coreferentiality, and qualification qua relations. Methodologically, philological care is paired with formal logical analysis on the basis of 'Navya-Nyāya Formal Language' premises and an axiomatic set theorybased approach. This study is intended as the first step of a broader investigation dedicated to analysing causation and transformation in non-difference.
\end{abstract}

Keywords Non-difference · Coreferentiality · Qualification · Relation

\section{Abbreviations}

a Primitive term (lowercase italics)

$-^{t} \quad$ Abstraction functor, expressing the Sanskrit

A Suffix -tva or -ta

$\left|a_{t}\right| \quad$ Extension of an abstract; $\left|a_{t}\right|=\mathrm{A}$

$R \quad$ Relation $R$ (capital italics)

$\boldsymbol{R} \quad$ Relational abstract (bold capital italics)

$R^{\left(R^{\prime}\right)} \quad$ Relation $R^{\prime}$ interpreted as $R$, salva veritate

$R$ [A] The relation $R$ set of destination; for $R: \mathrm{A} \mapsto \mathrm{B}$, $\operatorname{dom} R \subseteq \mathrm{A}, \operatorname{ran} R \subseteq \mathrm{B}$, and $R[\mathrm{~A}]=\mathrm{B}$

\urcorner$\quad$ Avacchedaka operator; identifying the limitor of a relational abstract

ᄂ $\quad$ Nirūpaka operator; identifying the conditioner of a relational abstract

. Niștha operator; connecting an abstract to a primitive term

Alberto Anrò

alberto.anro@unito.it

1 University of Turin, Turin, Italy 


\begin{tabular}{|c|c|}
\hline TvN & Tadvattva-Nyāya ('Axiom of Possession') \\
\hline SVN & $\begin{array}{l}\text { Samānāähikarana-Viśisțatva-Nyāya } \\
\text { ('Principle of Coreferential Qualification') }\end{array}$ \\
\hline${ }^{*} \varphi$, & 'It is false that $\varphi$ ' \\
\hline
\end{tabular}

\section{Pariṇāma-vāda and atyanta-abheda}

The Maharashtrian encyclopedic writer Bhāskararāya Makhin, flourishing in TamilNadu in the first half of XVIII c., was a prominent figure of the Tantrik śákta school commonly known as Śrīvidyā. Highly learned and prolific, calling himself genuinely Tantrik (tāntrika) and fully Vedic (vaidika) at once, Bhāskararāya relentlessly pursued his effort to harmonize the main tenets of the Srīvidyā school with the most authoritative sources of the brahmanical milieu-the Vedic (śruti) and post-Vedic (smrti) corpora, first and foremost, as well as his repeatedly declared affiliation with the advaita-vedānta tradition. In Varivasyārahasya 3 (VVR 3), along with his Prakāśa auto-commentary (VVR-P 3), Bhāskararāya describes the nature of mahat-prakāśa, the great radiance. ${ }^{1}$ Once that light (jyotis)—which is brahman and unobstructed (anāvrta) ätman-is known, every other thing is known as well. ${ }^{2}$ This alone is the true fundament (adhișthāna). That ultimate (carama-vrtti), indeterminate (nirvikalpa), transformation of cognitive motion will definitely obliterate (nāśyatva) all further content. The phenomenal object (drísya)—

\footnotetext{
1 VVR 3 (1976, pp. 4-6): sa jayati mahān prākaśo yasmin dṛște na dṛ́syate kim api I katham iva tasmiñ jñāte vijñātam ucyate vede II. VVR-P 3: sa sarveșām ātmatvena prasiddhah I mahān deśakālādyanavacchinnah parāprakāśyah, prakāśah sarvadā anāvṛtātmasvarūpajyotiḥ i; "That Great Radiance triumphs, at the sight of which nought else is seen. How then is it said in the Veda-s that all is known on Its being known!’. About Bhāskararāya (1690-1785), see Sanderson (2014, p. 72) and Śāstrī in VVR (1941: XXIII-XLIII, Introduction). Concerning the śaiva-śākta school termed Śrividyā ('Auspicious wisdom') Bhāskara belongs to, cf. Goudriaan (1981: part I); Brooks (1992, 1998). About śākta schools: Goudriaan (1979, pp. 6-7); Sanderson (1988); Sanderson (2014, pp. 65-91). Padoux (YH 1994, p. 15): "The philosophical notions of Yoginīhrdaya [and VVR, consequently] are those of non-dualist Kashmir Śaivism. The supreme Reality is transcendent, without division (niṣkala), transcending space and time, pure light (prakāśa), consciousness (samvit). It is also the phoneme $A$, the 'peerless one' (anuttara). This absolute flashes forth, vibrates luminously (sphuratta, ullāsa). It expands as a luminous wave (sphuradūrmi) by its own free will (svecchayā), and thus manifests the cosmos made up of the thirtysix tattvas, from Śiva to prthiv $\vec{\imath}$ '. Regarding VVR's genealogical dependence on Yoginīhrdaya, cf. also Anrò (2019). Nonetheless, by his own admission, Bh. considers his account to be not in contrast, if not in complete compliance, with Śankara's theses; cf. VVR-P 3 (1976, p. 6). On the connections between Śrīvidyā, advaitavedānta and orthodox brahmanical milieu, cf. in particular Pellegrini (2013, pp. 53-81); regarding the self-understanding and cultural impact of śākta intellectuals of South India, see Fisher (2012).

2 VVR-P 3: yasminn adhiṣthāne dṛște nirvikalpātmakacaramavṛttivișaȳkrte sati kim api dṛśsam na dṛśyate, adhișthānajñānanāśyatvāt I. Cf.: (1) Bṛhadāranyaka Upaniṣad 2.4.5: ātmā vā are drașțavyah śrotavyo mantavyo nididhyāsitavyo maitreyi I àtmano vā are darśanena śravaṇena matyā vijñānenedam sarvam viditam II; (2) Muṇdaka Upaniṣad 1.3: śaunako ha vai mahāśālo’ngirasam vidhivad upasannah । kasmin nu bhagavo vijñāte sarvam idạ̣ vijñātam bhatīti II; (3) Chāndogya Upanișad 6.1.3: śvetaketo yan nu somyedam mahāmanā anūcānamān̄i stabdho'si I uta tam ādeśam aprākṣyah yenāśrutam śrutam bhavaty amatam matam avijñātam vijñātam iti I katham nu bhagavaḥ sa ādeśo bhavatīti II.
} 
denotable (gamya) by means of the demonstrative pronoun 'this', idam-is but a real transformation (parināma) of 'that [sole reality]' (tat=ahamtā-rūpa-śaktiviśișta-brahman). ${ }^{3}$ That is, between 'power' (śakti) and 'power-owner' (śaktimat) and between the material cause (upādāna) and what is caused (upādeya), there is absolute non-difference (atyanta-abheda). ${ }^{4}$ Bhāskararāya highlights that all Vedic passages (śruti) — the peak (mūrdhanyā) of all means of true cognition (pramāna) concerning non-duality and every Tantra consistent with the former agree on this issue (abhiprāya). "Brahman, you see, is this whole world" (Chāndogya Up. 3.14.1: 209): syntactical homogeneity (sāmānādhikaranya), claims Bhāskara, expresses non-difference (abheda) and the absence of any contradiction (bādha). ${ }^{6}$ While the two 'differential counterparts' (bhedāmśa) effect (kārya) and cause (kārana) manifest as constructs (kalpita), the entire phenomenal extension (prapañca) does not. ${ }^{7}$ Negation concerns only the facet (amśs a) of difference. Passages such as "there is nothing diverse at all here!" (Brihadāranyaka Up., 4.4.19: 125; Katha Up., 4.11: 395) or "one only, without a second one" (Chāndogya Up., 6.2.1: 247) refer to the absence (abhāva) of that which possesses difference (bhedavat) by reason of the lack (abhāva) of any qualifier (viśeșana). ${ }^{8}$ The features of Bhāskara's thesis are therefore: full agreement with the śruti, absolute nondifference (linguistically expressed by syntactic homogeneity), radical negation of any difference but not of what is differentiated (that is, phenomenal manifestation), and the absence of any qualifier to differentiate real transformation. Bhāskara supports his thesis by referring to the section of Vācaspati Miśra's Bhāmatī (IX-X c.; hereafter VM-B) dedicated to the 'golden crown' (hätaka-makuța). " "The property of possessing a [degree of] reality (sattākatva) that is [ontologically]

\footnotetext{
3 VVR-P 3: parāhaṃtām antareṇedamtāyā asaṃsphuraṇād ahamidamoh sasambandhikatvād idam

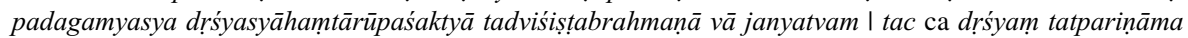
eval.

4 VVR-P 3: śaktiśaktimator upādānopādeyayor atyantam abhedah I.

5 VVR-P 3: advaitaśrutayah sarvā api etadabhiprāyikā evāviruddhāh I sarvapramānamūrdhanyayā śrutyā tadanusāritantraiś cādvaite kathite I.

6 VVR-P 3: ata eva "sarvam khalv idam brahma" iti sāmānādhikaranyam abhede, na punar bādhāyām I. Cf., Chāndogya Upaniṣad, 3.14.1: sarvam khalv idạ̣ brahma tajjalān iti śānta upāsìta I atha khalu kratumayah puruṣo yathākratur asmiṃl loke puruṣo bhavati tathetah pretya bhavati I sa kratum kurvīta II.

7 VVR-P 3: tadviruddhatvena bhāsamānah kāryakāranayor abhedāmísa eva kalpita āstām na punah sarvo'pi prapañcah $\mathrm{I}$.

8 VVR-P 3: "neha nānāsti kimcana” ityādi śrutișv api bhedāṃśasyaiva niṣedho na prapañcasya | "ekam evādvitīyam" ityādau śrūyamāṇo bhedavatprapañcābhāvo’pi viśeșaṇābhāvaprayukta eva I. Cf.: Bṛhadāranyaka Upaniṣad, 4.4.19: manasaivānudraștavyam neha nānāsti kiṃcana I mṛtyoḥ sa mṛtyum āpnoti ya iha nāneva paśyati II; Kațha Upanișad, 4.11: manasaivedam āptavyaṃ neha nānāsti kimcana । mrtyoh sa mrtyum gacchati ya iha nāneva paśyati II; Chāndogya Upaniṣad, 6.2.1: sad eva somyedam agra āsìd ekam evādvitīyam I tad dhaika āhur asad evedam agra āsìd ekam evādvitīyam I tasmād asatah saj jāyata $\|$.

9 Vācaspati Miśra, Bhāmatī(VM-B, pp. 72-73); section named by Bhāskara as 'hātaka-makuṭa-grantha', 'the golden crown section' or 'section concerning gold and crown'. Comm. to Brahmasütra 1.1.4 (samanvayādhikaraṇa, 4): tat tu samanvayāt. Chakraborty (1967, p. 42): "Bhāmatī also is an important commentary of Śäriraka bhāṣya [the Śankara's commentary on Brahma-sūtra]. [...] The Bhāmatī school originates out of Bhāmatī. [...] Bhāmatī plays an important role in the interpretation of Śamkara Vedānta. Of course, the orthodox thinkers think that Vivarana [the mainstream line of interpretation based on
} 
inferior (nyūna) to gold is said solely of difference, not of the crown; since [what results from] transformation (parināma) possesses by necessity (avaśyakatva) the very same (samāna) [degree of] reality as that which has transformed (pariṇāmin)" ${ }^{\prime 10}$

Needless to say, "the main concern of the Advaitin is to establish non-duality (advaitasiddhi). Of course advaitabrahman is always a self-established reality (svatahsiddha), auto-luminous (svaprakāśa), pure consciousness (śuddhacaitanya), so no proof is necessary to establish it. As consciousness requires no proof, [usually it is first and foremost] the falsity of the world alone [that] is to be established. Once established the falsity of the world [and this is the keystone of the argument], the non-duality becomes automatically established" (Pellegrini 2014, pp. 3-4). ${ }^{11}$ The strategy advanced by Bhāskara appears instead to be symmetrically opposite. Here, the aim is to harmonise, in strictly non-dual terms, the brahman-ätman autoevidence with the full reality of manifestation. In other words, the advaitin's first move usually consists in proving the falsity (mithyātva) of the world (prapañca, or jagat) in order to validate the reality and unity of brahman: where I saw a snake, there is but a rope. So, where is the difference between snake and rope, if there is no snake? In this case, however, Bhāskara draws on Vācaspati to overturn the question. It is no longer a matter of denying the reality of the world, but rather of denying only the reality of difference-and this becomes the keystone of his argument. How to fully conceive the difference, if there is one, between a crown and the gold of

\footnotetext{
Footnote 9 continued

Padmapāda's Pañcapādikā] represents Śankkara more faithfully than Bhāmatı̆’. Potter (1981, p. 17): "Vācaspati Miśra is said to have continued Mạ̣dana's brand of Advaita in a commentary now lost, on the Brahmasiddhi and in his Bhāmatī on Śaṅkara's Brahmasūtrabhāṣya". Potter (2002, pp. 172-173): "One model, known as 'limitationism' (avacchedakavāda), derives from the fact that there are entities that we ordinarily assume not to break into parts even when they are limited by other entities. For example, the general property of blueness remains general even though at this moment it is instantiated in the cover of the book at my elbow; the particular spatio-temporal location of it is merely accidental and does not affect the essence, blueness. [...] A second model [is] known as 'reflectionism' (pratibimbavāda) [...]. The tradition is that the Bhämatī school propounds limitationism and the Vivarana school reflectionism [...]". For a detailed analysis of Vācaspati's main philosophical tenets, cf. also Ram-Prasad (2002, pp. 95-132). Regarding contrasting models within Advaita, cf. also: Timalsina (2006, pp. 21-24). For a general survey on Śankara and his Brahmasūtrabhāşya, cf. Potter (1981, pp. 115-179). For a well-documented survey of the complex mutual interchange between the Advaita and Nyāya schools, cf. Phillips (1997).
}

10 VVR-P 3: ata eva bhāmatyām hātakamakuṭagranthe bhedasyaiva hāṭakanyūnasattākatvam na makuțasyoktam, parịnāmasya parin̄āmisamānasattākatvāvaśyakatvāt I "māyāmātram idam dvaitam" (Gauḍapādīya-kārikā, 1.17) ity atrāpi dvaitaśabdena bhedasyaiva mithyātvam ucyate, na punar bhedavatah $\mathrm{I}$.

11 A quote analysing a passage of Madhusūdana Sarasvatı̄’s Advaitasiddhi (cf. AS 1997, p. 8; tatrādvaitasiddher dvaitamithyātvasiddhipūrvakatvād dvaitamithyāvam eva prathamam upapādanīyam); additions in square brackets are mine. Cf. also Chakraborty (1967, p. 41): "Śamkara interprets Brahma Sütra in his own way and shows that the consistency of the upanișadic texts can alone be maintained on the admission of the sole reality of consciousness and falsity of the world". On this point, see also Timalsina (2009, p. 85): "There are two ways Advaita can be established: by confirming the existence of a singular reality, or by rejecting the existence of duality". 
which it is made? If there is no difference, where is the difference between jagat and brahman $?^{12}$

If "Advaitins [undoubtedly] place the stream of arguments that refute difference at the core of their logical investigation", in so doing, "they first utilize the categorical analysis found in Nyāya" (Timalsina 2009, p. 86; cf. also Ganeri 2011, pp. 223-236), just as this paper is methodologically proposing to do. Indeed, the highly refined language and techniques of Navya-Nyāya-along with the formalistic methodology derived therefrom, named 'Navya-Nyāya Formal Language' (NL; cf. infra) - will be here programmatically adopted in order to describe in detail a non-dualistic argumentative architecture. Clearly, this does not imply that the Naiyāyikas' account, conceived in its own prerogatives, will be considered interchangeable or confusedly intermingled with the Advaitins' one. On the contrary, the philosophical claims of NL qua hermeneutical device methodologically stop just before being committed to the various and different theoretical frameworks NL purposes to analyse (cf. Anrò, forthcoming). This therefore means that, despite the respective deep structural differences, the Nyāya machineryenvisioned, in accordance with a well-established tradition, as a 'lingua franca for intellectual exchange' (Ganeri 2011, p. 223)—will be here methodologically put at the service of Vācaspati's reasoning, in its turn viewed through the lens of the issue Bhāskara raised.

\section{Syntactic Homogeneity and Coreferentiality}

What is this golden bracelet? Undoubtedly, it is gold. It is, in this perspective, nondistinct (a-bhinna) from its cause (kārana) because, as stated above, the bracelet is golden. Nevertheless, it is also a bracelet, and not another ornament such as an earring or crown. Indeed, the bracelet is distinct as an effect (kārya) exactly because

\footnotetext{
12 Dasgupta (1933, pp. 161-162): "If, however, it is contended that this view of real transformation is only from a relative point of view, then there must be at least one sütra where the absolute point of view is given; but no such sütra has been discovered even by Śankara himself. If experience always shows the casual transformation to be real, then how is one to know that the ultimate point of view of all effects are false and unreal? If, however, it is contended that there is a real transformation of the $m \bar{a} y \bar{a}$ stuff, whereas Brahman always remains unchanged, and if $m \bar{a} y \bar{a}$ is regarded as the power of Brahman, how then can the power of Brahman as well as its transformation be regarded as unreal and false, while the possessor of the power is regarded as real and absolute? [...] The world is identical with Brahman, inasmuch as it has been and is identical with being, and different from it, inasmuch as it has its characteristics of materiality and change". Dasgupta (1941, p. 333): "But in passages like those found in Śankara's bhāsya on the Brahmasütra, I.1.2, it might appear as if the world-phenomena are no mere appearance but are real, inasmuch as they are not merely grounded in the real but are also the emanations from the real- the Brahman. But strictly speaking Brahman is not alone the upādana or the material cause of the world but Brahman-with-avidy $\bar{a}$ is the material cause of the world and such a world is grounded in Brahman and is absorbed in Him; and Vācaspati in his Bhāmatī on Śankara's bhāṣya on the same sūtra (B.S. I. 1.2) makes the same remark. [fn. 1] avidyā-sahita-brahmo-pādānam jagat brahmany evāsti tatraiva ca lìyate. Bhāmat̄i, 1.1.2.". For a preliminary survey of Vācaspati's tenets about māyā, cf. Potter (2002, pp. 168171); on causal chain and causal models in Indian philosophical systems, cf. Potter (2002, pp. 102-115).
} 
it is a bracelet and not an earring. It seems, thereby, to appear as simultaneously distinct and non-distinct. ${ }^{13}$

The notion (pratyaya) of sāmānādhikaranya indicates syntactical homogeneity on the linguistic and grammatical level, and coreferentiality on the ontological one, both at the same time. Using this notion to express the relationship between earring and gold clearly exhibits the simultaneous occurrence of difference and nondifference (bhedābheda). ${ }^{14}$ In Vācaspati's view, the sāmānādhikaranya relation acts as the ratio cognoscendi with respect to the $a$-bheda relation, for its part the ratio essendi of the former. This relationship of sāmānādhikaranya between two terms in a Sanskrit sentence-terms which share the same grammatical ending (say, nominative or first ending) and the same referent, here generically named A and B - can be expressed in the following manner ${ }^{15}$ :

\section{[1] $\mathrm{A}^{1} \mathrm{~B}^{1,}$ ' $x$ is $y$ ' (e.g. kuṇdalam suvarnam, 'The earring is gold').}

Vācaspati points out that sentences such as [1] are not in any way reducible to the substratum-superstratum relation (ādhāra-ādheya-bhāva): if $\mathrm{A}^{7} \mathrm{~B}^{1}$ ('B on/in $\mathrm{A}$ '), e.g. kunde badaram ('A jujube in a bowl'), this does not imply that the fruit is the bowl (na hi bhavati kundam badaram iti); or to the relation of 'residing in one locus'

13 VM-B: 73: bhinnābhinnam tad iti cet; tathā hi tad eva kāraṇātmanābhinnam, bhinnam ca kāryātmanā, kațakādaya ivābhinnā hātakātmanā bhinnāś ca kațakādyātmanā. And also: athānuvṛttivyāvṛttivyavasthā ca hemni jūāte kuṇdalādijijñ̄āsā ca katham? na khalv abhede aikāntike'naikāntike caitad ubhayam upapadyate ity uktam; "Then, how is that [particular] state of affairs (vyavasthā) between continuity (anuvrtti) and discontinuity (vyāvrtti) [possible]? And [how is it possible that] once having known gold, the necessity of knowing (jijñ̄assa) earrings, etc., still remains? Indeed (na khalu), in absolute and nonabsolute (an-aikāntika) non-difference, it has been said they are both possible (upapad)". The issue is also addressed in the same terms by Vrșabhadeva in his Paddhati to Bharț̣hari's Vākyapadīya 1.59 (1966, p. 117). There, the chosen example is a golden ring (suvarna-aingulizyaka) and it is a case of vyapadeśivadbhāva. Vyapadeśivadbhāva is defined an extension of a specific designation (vyapadeśa): "fait que (tel mot est traité) comme s'il avait reçu une désignation speciale", Renou (1957, pp. 295-296). The canonical example concerns the mythological episode of Rahu's head: if only his head is left, what could be meant by the expression 'Rahu's head' (rahoh sirah)? Indeed, a distinction is still suggested even where there is no more duality. In this passage, Vrșabhadeva combines the Rahu example with the 'golden ring' case of vyapadeśivadbhāva: that is, a specific designation in abheda to define the specific nature of the matter, where there is but a single object. Highlighting the same topic, cf. Candotti (2005, p. 337).

14 VM-B: 72: 'kuṇḍalam idạn suvarṇam' iti sāmānādhikaranyapratyaye vyaktam bhedābhedau cakāstah̆; tathā hi ätyantike'bhede'nyatarasya dviravabhāsaprasaìgah; bhede cātyantike na sāmānādhikaranyam gavāśvavat; ādhārādheyabhāve ekāśrayatve vā na sāmānādhikaranyam; na hi bhavati kuṇ̣̂̆ badaram iti; nāpy ekāsanasthayoś caitramaitrayoś caitro maitra iti I. Cf. Filliozat (1988, p. 69): "Le rapport du mot et de ce à quoi il réfère dans la réalité objective est donné comme un rapport de location: l'objet signifié est la location (adhikaraṇa) ou le support (ädhāra) du mot. [...] On dit que les mots sont samānādhikarana littéralement 'ont la même location', s'ils réfèrent au même objet. L'identité de location est l'identité de référence dans la réalité objective". Cf. also Staal (1988, p. 62), who sets off from Jagadīśa Bhațạāārya's definition of tatpuruṣa, quoted by Nyāyakośa (cf. infra), and clearly formalises "sameness of locus" as: $\mathrm{K}(\mathrm{p})={ }_{\mathrm{d}}\left\{\mathrm{C}_{\mathrm{k}}(\mathrm{t}, \mathrm{p}) \wedge[\mathrm{axB}(\mathrm{x}, \mathrm{t})=\operatorname{axB}(\mathrm{x}, \mathrm{p})]\right\}$.

15 Capital letters, such as $\mathrm{A}$ and $\mathrm{B}$, stand for terms while, according to a longstanding tradition (cf. kaumudī corpus, i.e. grammatical commentaries), superscripts stand for the grammatical endings (vibhakti) in which the terms appear. So, e.g. ' $\mathrm{B}^{1}$ ' will mean 'the term $\mathrm{B}$ in the first case or nominative' (prathamā vibhaktih); and ' $\mathrm{A}$ ', will mean 'the term $\mathrm{A}$ in the seventh case or locative' (saptami vibhaktih). For this updated usage, cf. Ganeri (2006, p. $36 \mathrm{ff})$. 
(ekāśrayatva): $\mathrm{C}^{7} \mathrm{~A}^{1} \mathrm{~B}^{1}$ ('A and $\mathrm{B}$ on/in C'). If 'Caitra and Maitra [are dwelling] on the same seat' (ekāsane caitramaitrau) it does not follow that 'Caitra is Maitra' (cf. fn. 14).

Two possible interpretations of [1] are then formulated in Vācaspati's analysis. [a] The relation of sāmānādhikaranya can point to an absolute non-difference (atyantika-abheda) according to which in [1] A = B; e.g. 'The earring is gold', that is, 'earring = gold'. However, based on this premise, what will occur is the undesired outcome (prasanga) of a double occurrence (dviravabhāsa) of the term itself: if $\mathrm{A}=\mathrm{B}$, then $\mathrm{A}=\mathrm{A}$ or $\mathrm{B}=\mathrm{B}$. Thereby, if 'earring = gold', then: 'earring = earring'; or 'gold $=$ gold' ${ }^{16}[b]$ In the case where, in order to avoid the doble occurrence at point $[a]$, the total difference (ätyantika-bheda) between the two terms in [1] is stressed, then $\mathrm{A} \neq \mathrm{B}$, with the likewise undesired consequence that any form of sāmānädhikaranya relation would be then denied-as in the case of gofaśva (cow $\neq$ horse). Thus, if $\mathrm{A} \neq \mathrm{B}$, then: earring $\neq$ gold $\neq$ horse.

Still claiming [1], it is therefore not possible to conclude either that the erring is gold, without falling into $[a]$, nor that the earring is not gold, without falling into $[b]$. The relation of sāmānādhikaranya - while being unobstructed (abādhita), indubitable (asamdigdha) and universal (sarvajanina) —ends up determining (vyavasthā) both the difference and the non-difference between the effect (earring) and its cause (the gold of which it is made), simultaneously. ${ }^{17}$

\section{Cognition as a Relation}

If the relation of difference (bheda or dvaita; $\mathrm{A} \neq \mathrm{B}$, e.g. go $\neq a s$ va) does not seem to present any difficulty, what kind of a relation is there between the two terms of a non-difference? Since non-difference (hereafter expressed by the strikethrough

\footnotetext{
16 The logical fallacy of ätmäśraya ('self-foundation') is a vicious circle or self-dependency (sva-apekșa $)$ in cognition. Cf. Jha (2001, p. 84). NK, p. 121. ātmäśrayah-tarkah [ka] svasya svāpekșāpādakah prasangah (Jagadīśa Bhațāāārya, Jagadīsisi; Id., Tarkāmrntam) | yathā kāryatvāvacchinnakāryatānirūpitakāranatvam sädhäranakäranatvam ity ādau I atra ekam käryatvam avacchedakam I aparam tv avacchedyam I tathā cāvacchedakajñānam vinā avacchedyajñānam na bhavati I avacchedyajñānam vināpy avacchedakajñānam ca na bhavati I parasparasāpekșatvād ity ātmāśraya iti bodhyam I. "[The term] 'self-foundation' (ätmäśraya) must be understood as a circular (paraspara) [vicious] self-dependancy (sva-apekșā). Like in cases such as 'generic causeness' (sädhärana-kāranatva), where the property of being a cause is both conditioned by effectness (käryatva) and limited by [the same] effect-ness $(k \bar{a} r y a t \bar{a})$ '. Here effect-ness is the limitor; nonetheless, [yet] it is [also] the limited too. But, a knowledge of the limited without the knowledge of limitor cannot be, and vice versa." With the term sādhārana ('generic') is indicated the fallacy of anaikāntika ('inconclusive' [probans]). Cf. NK, pp. 998-999: sādhāranah-hetvābhāsah duștahetuh I [ka] sapakșavipakșavrttir hetuh (Viśvanātha Pañcānana Bhațāāārya, Bhāssāpariccheda, 2, śl. 74) I yathā parvato vahnimān prameyatvāt ity ädau prameyatvam hetuh sädhāraṇah I; "it is 'generic' an apparent or fallacious probans; it consists in being a probans which occurs both in similar and dissimilar instances. In examples such as 'the mountain possesses fire by virtue of the probandum', it is 'generic' the probandum as probans". Cf. also, NK, pp. 36-37: anaikāntika-hetvābhäsah [...] anaikāntikah savyabhicāraśabdena vyavahriyate I; 'It is 'inconclusive' a fallacy concerning probans; it is commonly referred to by the term deviation (or discrepancy). Perfectly analogous is the definition of savyabhicāra: cf. NK, pp. 979-980.

17 VM-B: 72: so'yam abādhito ’samdigdhạ sarvajanīnah sāmānādhikaranyapratyaya eva kāryakāranayor bhedābhedau vyavasthāpayati. It has been said that Vācaspati asserts, moreover, that the issue cannot be solved by appealing to the relation of 'substratum-superstratum' ( $\bar{a}$ dhāra-ädheya-bhāva) nor to the property 'residing in one locus' (eka-äsraya-tva): in these cases there is no coreferentiality at all, which is, on the contrary, the starting point of the analysis.
} 
cypher ' $z$ ', i.e. advaita, lit. 'non-two') cannot be reduced to an equality or identity relation $(\mathrm{A}=\mathrm{B})$, how can these two terms be simultaneously equal and different, as explicitly claimed by Vācaspati?

Some formal tools are required to perform the analysis in NL (Navya-Nyāya Formal Language). ${ }^{18}$ Let the notation ' $\_t$ ' be here the abstraction functor, capable of expressing the Sanskrit suffix $-t v a$ or $-t \bar{a} .^{19}$ So, for instance, if the primitive term $g$ (small italics) is a single pot (ghata), ${ }^{20}$ then ' $g_{t}$ ' $=$ 'the property of being $g$ ' or ' $g$ hood' (i.e. ghatatva, 'pot-hood') whose extension corresponds to the set 'pots' G (capital), to obtain $\left|g_{t}\right|=\mathrm{G}$. According to what could be called the Axiom of Possession or Tadvattva-Nyāya (TvN), the element $g$ is said to belong to the set $\mathrm{G}$ because $g_{t}$-possessing (viz., qualified by the property $g$-hood $=$ pot-hood). Thus ghațo ghațatvavān, 'a pot [is a pot because it is] in possession of pot-hood', lest it be not the pot it is. More generally, TvN: tadvattvam (in extended form, taddharmavattvam or tattvavattvam) tad eva, "What possesses the property of being that, is that'. ${ }^{21}$

That premised, the crown $(m)$ is surely gold $(h)$. What would be left, indeed, if the gold of which the crown is made were subtracted? Thus, $m=h$. Nevertheless, $m \neq h$ because the crown is not only gold, it is a crown as well. Saying that 'the crown is gold' implies two distinct properties: the abstract properties 'gold-ness', hâtakatva $\left(h_{t}\right)$, and 'crown-hood', mukutatva $\left(m_{t}\right)$, in reference to the two distinct sets $\mathrm{M}$ (the set Crowns; for $m \in \mathrm{M}$ and $\left|m_{t}\right|=\mathrm{M}$ ) and $\mathrm{H}$ (the set Gold; for $h \in \mathrm{H}$ and $\left|h_{t}\right|=\mathrm{H}$ ).

\footnotetext{
${ }^{18}$ For a discussion of NL technicalities, scope, and aims and the strengths and weaknesses of such an extensional set-theoretic approach, cf. Anrò (forthcoming). Regarding the strategy of using a set-theoretic ontology, cf. Ganeri (2008, p. 112 ff.). For a general survey of axiomatic set theory, see Jech (2006, pp. 313). NL is directly inspired by Ganeri (2008 I \& II).

${ }^{19}$ Ganeri (2008, p. 113): on "abstraction functor". The abstraction functor ' $t$ ' here plays the roleincluding in a graphic sense—of Ingalls' subscript convention 'locus ${ }_{1}$ ' for 'locus-hood' (e.g. Ingalls 1951, p. 46); ' $t$ ' clearly stands for '-tva' or ' $t \vec{a}$ '.

${ }^{20}$ A primitive term-expressed in NL by a small letter in italic (e.g. ' $g$ '), that is, by a "simple symbol" refers to an "individual or a particular", cf. Russell (1919, pp. 141-143, 173): "a 'simple' symbol is one which has no parts that are symbols".

${ }^{21}$ Alternatively, tadvattā (that is taddharmavattā or tattāvattā) tad eva; cf. Anrò (forthcoming). Similarly, in sentences such as 'ghate ghatatvam', the locative of residence (vrttitva) denotes the relation ' $\in$ '; $g \in(\mathrm{G}=$ $\left.\left|g_{t}\right|\right)$. Cf. Ganeri 2008, pp. (128, 131-132); and Matilal (1998, p. 29): " $x+v a t+t v a=x$ ”. Cf. Pāṇini (1999, p. 569) sū. 5.2.94: "tad asyāsty asminn iti matup [...] A taddhita affix, namely matUP, occurs to denote the sense of sasthī 'genitive' (asya), or of saptamī locative (asmin), after a syntactically-related nominal stem which ends in pratham $\bar{a}$ 'nominative', provided it is qualified with the denotatum of asti 'existence". According to Shaw's terminology, TvN expresses an "atomic cognition", while a property $(\mathrm{P})$ may be defined as "( $\square x)(x$ is a locus of $\mathrm{P})$ " (1989: 382 et passim). Cf. also Staal (1988, p. 63); in his notation: ax B $(x, t)=t$.
} 
Clearly, these two properties could be structured around three possibilities: golden crowns, golden bracelets and iron crowns could exist. ${ }^{22}$ In current notation:

[a] $(\exists x)(\mathrm{M} x \wedge \mathrm{H} x)$-hāțakam mukuțam ( $\mathrm{A}^{1} \mathrm{~B}^{1}$; 'A golden crown'); in case both qualificans and qualificandum are present: ubhaya-bhāva-prayuktaviśișta-bhāva.

[b] $(\exists x)(\mathrm{M} x \wedge \mathrm{H} x)$-hātakam na mukuṭam or hātakam makuțānyatvam $\left(\mathrm{A}^{1} \mathrm{~B}^{1}\right.$; 'Gold which is not a crown'); in case the qualificandum is absent and qualificans present: viśeșyābhāva-prayuktaviśiștābhāva, viśeșanabhāva-prayuktaviśișta-bhāva. ${ }^{23}$

[c] $(\exists x)(\mathrm{M} x \wedge \mathrm{H} x)$-ahātakam mukuțam ( $\mathrm{A}^{1} \mathrm{~B}^{1}$; 'A non-golden crown'); in case the qualificandum is present and qualificans absent: viśesya-bhāva-prayuktaviśisțbhāva, viśeșanābhāva-prayuktaviśiștāah hāva.

Nevertheless, the conjunction expressed in standard notation for assertion [a] cannot be considered fully proper from a Naiyāyika's perspective. "Nyāya develops a language which can perhaps be given the appellation of a 'property-location language' $[. .$.$] . The model sentence of such a language contains the introduction of$ general concepts and 'the indication of their incidence'. Under this interpretation, the qualifier can be viewed as the feature-universal [...], and the qualificand can be viewed as the locus where the qualifier is said to occur" (Matilal 1968: 16). ${ }^{24}$ For a

\footnotetext{
${ }^{22}$ I ignore as being superfluous to my argument here the fourth possibility in which both properties are negated: ubhayābhāva-prayuktaviśiștābhāva, 'absence qualified by the absence of both qualificandum and qualificans'. Being not crowns or gold, there would be, for instance, gingerbread or whatever else. I refer here to the inferential taxonomy displayed by Viśvanātha's Muktāvalī when discussing the "governing factors" (prayojaka) for "qualified negation" (viśiștābhāva)" as conditions for inferential subjectness (pakșatā). I add here a fourth possibility (case [a]) not present in the original text: ubhaya-bhāva, or double presence. Cf. NSM (1988: 496-506) and Rai (1995, pp. 6-7), also quoted by Pellegrini (2014, p. 12).

23 Instead of the perhaps more common ' $\neg$ ', I will use the tilde operator $(\sim)$ as negation functor here to avoid any confusion with the NL operator top left corner ( $\urcorner$ ); cf. infra fn. 51-52.

24 Cf. also Matilal (1968, p. 32): Naiyāyikas "tended [...] to speak in terms of dharma (property) and dharmin (property possessor or locus of property"; and Matilal (2001, p. 202): "A simple qualificative cognitive state is one where the cognizer cognizes something (or some place or some locus, as we will have to call it) as qualified by a property or qualifier. It is claimed by most Sanskrit writers that to say that something or some place is qualified by a qualifier is equivalent to saying that it is a locus of some property or locatable". The concept of 'property' is used in this paper according to a principle of ontological parsimony, which naiyāyikas name lāghava: "It seems that Nyāya tries in the main to avoid disputes about ontology, and develops a theoretical language which can be used even by those who do not share its ontological dispositions (cf. [16, p. 66], [3, p. 201])", Ganeri (2008, p. 112), quoting B.K. Matilal and S. Bhattacharyya. Cf. also Matilal (2001, pp. 208-209): "Suppose by 'property' we mean non-universal, abstract features, or even tropes"; the thought experiment of 'ability to swim' and 'water'; and Matilal (2001, pp. 209-210) on the difficulties in translating dharma: "[...] the word dharma has a wider extension than the word 'property' [...]. Dharma sometimes means not only abstract properties or universals but also concrete features, that is, the particular features of some object or locus. Dharma and dharmin constitute a pair in Sanskrit that is the equivalent to the pair 'locatee' (or the locatable) and 'locus' (location, which may be a place or a time or even an abstract object)".
} 
Naiyāyika, a golden crown is a 'qualified entity' and, bizarre though it may seem at first glance, 'A golden crown is a crown' just as 'A blue pot is a pot'. ${ }^{25}$

In compliance with assertion [a], the statement 'A blue pot' can be plainly described, in standard notation and according to a predicative account, through the linear string $(\exists x)(\mathrm{G} x \wedge \mathrm{N} x)$, true iff 'There does exist a variable $x$ ', 'This variable is a pot' $(\mathrm{G} x)$, and 'This variable is blue' $(\mathrm{N} x) .{ }^{26}$ According to the Nyāya-propertylocation language (implying $\mathrm{TvN}$ ), the attribution of these properties would be better described not by the coordination of a double predication, but by a relational structure whose fulcrum is a primitive term and not an existing variable. In dealing with such a sentence, 'A blue pot', it must first be noted that the element under discussion here is relations, not predications. ${ }^{27}$ In general terms, this case of coreference could be seen as a viśeșana-viśeșa-bhāva, i.e. a qualifier-qualified relation, conceived as a form of determined cognition (savikalpa or viśișta jūāna). ${ }^{28}$

\begin{abstract}
${ }^{25}$ Nìlatva-viśișta-nīla-rūpa-vān ghațatva-viśiștah ghațh, 'a pot, possessing blue color in turn qualified by blue-ness, is qualified by pot-ness'; cf. Matilal $(1968$, p. 15), translation mine. The puzzle 'a pot = a blue pot' "[...] express a truism, viz., a thing is identical with itself no matter whether you refer to it in a general way (sāmānyena) by calling it a 'pot' or in a special way (viśeșena) by calling it 'a blue pot'."; Matilal (1968, p. 48). Cf. also Ingalls (1951, p. 69): "That which is expressed by 'pot' alone is the type of framework that subsists in all knowledges of pots. [...] If one does not accept [that 'blue pot $=$ pot'], one must admit that a blue pot is not a pot (cf. Raghunātha, Dìdhiti, 19-20; in Ingalls 1951, pp. 160-161)". Thus, viśișta (qualified) as 'accompanied by': "vaisisistyam ca sāhityam sāmānādhikaranyam vā jñeyam", according to the NK definition (cf. NK, p. 779 and Ingalls 1951, p. 69, fn. 137). In this case I follow Matilal (1968, p. 48) regarding Ingalls' positions (Id. 1951, P. 69); cf. also the reviews of Ingalls (1951) in Potter (1954) and Staal (1960).
\end{abstract}

${ }^{26}$ Quine (1981, p. 27): "To say that a city or a word has a given property, e.g. populousness or disyllabism, we attach the appropriate predicate to a name of the city or word in question". Cf. also Quine (1981: § 22. Class and Member, 119-123): "In such context ['Paris is a city'] 'is' expresses rather possession of a property, or membership in a class: Paris belongs to the class of cities [...]. It is this sense of 'is' that is rendered symbolically with ' $\in$ ': 'Paris $\in$ city' $[\ldots]$ '. Or, to put it in its simplest terms: "Traditional [western] grammar tell us that the simplest sentences are composed of a subject and a predicate. [...] [The subject] tell us what the sentence is about. The rest is the predicate: this tell us what is said about it"; Priest (2000, pp. 17-18). For a survey of "subject-predicate discourse" in the context of the problem of universals and realist-antirealist debate, cf. Loux (2006, pp. 21-27).

${ }^{27}$ Regarding the primacy of proposition and predication as conceived in Western logic, and its differences with respect to the Nyāya qualifier-qualified approach, cf. Matilal (2001, pp. 201-205): "Now, in the Indian context the basic combination is not called a proposition. It is a structured whole that is grasped by an atomic cognitive event. We call it an atomic qualificative (viśișta) cognition. [...] A qualifier and a predicate-property may not always be the same, such that we can say there is only a terminological variation". Regarding the "basic combination of predication" in propositions as the "focal point in current logic", Matilal quotes Quine $(1960$, p. 96) and Strawson $(1974$, p. 4). See also Shaw $(1976,1989,2010)$ and Staal $(1988$, p. 63): "Western thought is inclined to analyse a close relationship in terms of subject and attribute whereas Indian thought considers the relation to the adhikarana".

${ }^{28}$ Interpreting coreference as qualification will be discussed in Part 2. On "determinate and indeterminate knowledge", cf. Ingalls (1951, pp. 39-40). Cf. also Matilal (1968, p. 13): "The content of a qualificative cognition, then, taken as a whole, is articulated in such a way that a certain feature or features of it will be emphasized as features of, or occurrent in, or related to, the remaining portion or portions of the content. [...] Thus a qualificative cognition may be said to be an answer to question of the form: 'What is this?', 'What property does it possess?', 'When or where does it occur?"; and Id. (1968: § 3.7). See also Dalai (1992, pp. 10-13). Regarding jñanna-fundamentally as "cognition or psyche-dependent awareness" - see also Bilimoria (1985, p. 75): "we may note how jñanna is used [...] sometimes to indicate 'knowing' in the sense of 'propositional attitude' [Matilal (1968, pp. 8-9)] towards beliefs, or towards what one is actually believing and judging at some time, as would occur, say, in reflective and introspective states, where there 
The Nyāya relation-based analysis cannot therefore be directly reduced to predication, and any attempt to force the Nyāya account into this grid seems doomed to failure. If the first inaccuracy is thinking in terms of predication, the second is confusing the connective 'and' (' $\wedge$ '; which in the theory of sets corresponds to intersection, ' $\cap$ '), with the qualifier-qualified relation. ${ }^{29}$

The abstract property $g_{t}$ (ghatatva, pot-hood; cf. supra $\mathrm{G} x$ ) has as its locus the primitive term $g$-that is, an actual pot-while the further abstract property $n_{t}$ (nīlatva, blue-ness; cf. supra $\mathrm{N} x$ ) occurs in an instance of blue $(n)$, which is in turn located in 'a pot locus of pot-hood'. ${ }^{30}$ If the property $g_{t}$ (whose reference set is G) is referred to its locus g (ghata-niștha-ghațatva), then this property will be the prakāra or mukhya-viśeșana (chief or root qualifier) and the primitive term $g$ the mukhyaviśesya (chief or root qualificand). ${ }^{31}$ Yet, the root-property $g_{t}$ is in turn the locus of a colocated (samānādhikarana) second-order property $n_{t}$. In other words, $n_{t}$ (blueness) occurs in $g_{t}$ (pot-ness), referred to the primitive term $g$ (an actual pot). Thereby, the colocated second-order property $n_{t}$ turns out to be dependent on the first-order property $g_{t}$, the mukhya-viśeșana. Blue pots are thereby pots because blue-ness is

\section{Footnote 28 continued}

is affirmation of particular cognitive contents, as for example, when one becomes aware of 'table contentness' in his consciousness as his eyes fall on the large 'object' (this something) in the kitchen. The judgement is not about the 'object' as such, but it is an affirmation of his mental mode in relation to the object. However, often, too swift a move is made [...; thereby] when a reflective judgement is taken to be an assertion of the truth-value of a cognition, jūanna is rendered as knowledge, implying that it is a judgement with a truth-value [...]". In any case, the "significance"—in an "epistemic sense" —of a jñana is "having contentness: vișayatā"; Bilimoria (1985, pp. 76-77). Regarding viśeșya-viśeșana-bhāva-sambandha cf., of the many possible sources, Gadādhara (1990, pp. 125-126): "samsargatayā ca samam prakāratāyā viśeșyatāyāś ca nirūpyanirūpakabhāvākhyah sambandhaviśeșo'bhyupagantavyah | sa ca sambandhạ kāryatvakāranatvādheyatvādhāratvapratiyogitvānuyogitvādīnām mithas tādrísasambandha iva svarūpaviśeșah padārthāntaram eva vā, anyathā tatra tena sambandhena tat prakārakam ity etad arthasya durvacatvāt |. Translation: It is also to be admitted that there is a relation of determinerdetermined-ness between relationness, on the one hand, and modeness as well as qualificandumness, on the other. And that relation is either a particular self-linking relation or a separate ontological reality, just like the relation with cause-ness and effect-ness, superstratum-ness and substratum-ness, successor-ness and predecessor-ness. Otherwise the meaning of 'having that as a mode by that relation' cannot be explained". Regarding prakāratā, cf. also $\mathrm{NK}$, p. 515. 1) prakāratā-vișayatā | [ka] viśeṣaṇatvāparanāmā vilakṣaṇavișayatāviśeșah.

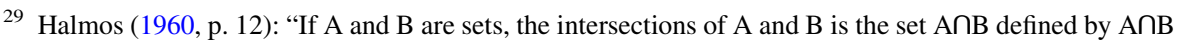
$=\{x \in \mathrm{A}: x \in \mathrm{B}\}$ ". Jech $(2006$, p. 8): "One consequence of the Separation Axioms is that the intersection and the difference of two sets is a set, and so we can define the operation $\mathrm{X} \cap \mathrm{Y}=\{u \in \mathrm{X}: u \in \mathrm{Y}\}$ and $\mathrm{X}-\mathrm{Y}=$ $\{u \in \mathrm{X}: u \square \mathrm{Y}\}$ "; Cf. also Enderton (1977, p. 21). For a plain explanation about the connections between basic operations on sets, Boolean operations, and Venn diagrams: Moschovakis (2006, pp. 2-4). Cf. also Levy (2002, pp. 244-246) on Boolean algebra; and Quine (1981, pp. 11-12) for an introduction to connective 'and'.

30 It must be noted here the absence of quantifiers, variables and operators, such as ' $\wedge$ ' (cf. $\exists x: m_{t}(x) \wedge h_{t}$ $(x)$ ). The NN logic syllabus thus basically consists of primitive terms, abstract properties, relational abstracts, and the two operators 'limitor' and 'conditioner'; cf. Anrò (forthcoming). Regarding the fact that "Indian logic has no variables" and the "strange doctrine of repeated abstraction" without quantifiers, cf. also Bochenski (1956, pp. 149-150).

31 Cf. Ingalls (1951, p. 43) and Matilal (1968, p. 15). 
dependent on pot-ness - which sounds quite striking if not wholly false. How could such a claim be justified? More generally, how could such a relation be conceived?

"Relation (sambandha) is what, though distinct (bhinnatva) from the relata (sambandhin), in them occurs (áśrita). [...] So, [for instance] contact (samyoga) [is the relation between] pot and ground; and direct contact (samnikarșa), in the case of perception, between sense organ and the [perceived] object" (NK, p. 920). ${ }^{32}$ Similarly, in set theory, a "pairing function" 33 or "relation is a set of ordered pairs" without any further restrictions: "any set of ordered pairs is some relation, even if a peculiar one" (Enderton 1977, p. 40). ${ }^{34}$ To put it another way, given two generic sets or classes $\mathrm{A}$ and $\mathrm{B}$, for $x \in \mathrm{A}$ and $y \in \mathrm{B}$, the relation $R$ is their Cartesian product (A B) written $x R y$ or $\langle x, y\rangle \in R$, in which $x$ stands in the relation $R$ to $y$. Conversely, any subset of ordered pairs, an element of the power set A B, is some sort of relation. ${ }^{35}$ "The domain of $R(\operatorname{dom} R)$, the range of $R(\operatorname{ran} R)$, and the field of $R(\mathrm{fld} R)$ [are defined] by: $(x \in \operatorname{dom} R) \leftrightarrow(\exists y)(\langle x, y\rangle \in R)$ [i.e., $x$ belongs to the domain of $R$ iff there exists at least an $y$, such that $x$ stands in relation $R$ with $y],(x \in \operatorname{ran} R) \leftrightarrow(\exists t)(\langle t$, $x\rangle \in R)$, and fld $R=(\operatorname{dom} R \cup \operatorname{ran} R$ ) [i.e., the union of the two]" (Enderton 1977, p. 40). Consequently, $R$ is a relation from A (set of departure) to $\mathrm{B}$ (the set of destination) iff: $R$ is a relation, $\operatorname{dom} R \subseteq \mathrm{A}$, and $\operatorname{ran} R \subseteq \mathrm{B}$. In other words, $R$ maps the image set of the

\footnotetext{
32 NK, p. 920. saṃbandham-1[ka] sambandhibhinnatve sati sambandhyāśritah | [kha] [...] yathā ghațabhütalayoh samyogah | yathā vā pratyakșasthale indryārthasamnikarșah |. Regarding the six kinds of "intercourse" (samnikarșa or sannikarșa; șațamnikarșa) in perception, cf. Sihna (1934, pp. 75-85): "Perception depends upon some sort of intercourse (sannikarșa) or dynamic communion between its object and a particular sense-organ". Contact or samyoga is the first samnikarșa, given the case of a substance (dravya; say, a pot) in union with the visual organ. See also Shaw (1989, p. 383; 2010, p. 626).

33 Bourbaki II.2.1-2 (1968, pp. 72-74) on "The axiom of ordered pair". Levy (2002, p. 24): "A very useful notion of set theory is the notion of a pairing function. A pairing function is a function $\langle x, y\rangle$ (with the arguments $x$ and $y$ ) such that: [...] 6.1 Definition (Wiener 1914, Kuratowski 1921) $\langle x, y\rangle=\{\{x\},\{x$, $y\}\}$. A set $z$ is said to be an ordered pair if for some $x$ and $y, z=\langle x, y\rangle$. 6.2 Proposition $\langle x, y\rangle=\langle u, v\rangle \rightarrow x=$ $u \wedge y=v$.". Cf. also: Levy (2002, p. 25): “A class $S$ is said to be a (binary) relation if every member $x$ of $S$ is an ordered pair. We shall write $y S z$ for $\langle y, z\rangle \in S$. For example, if $<$ is the natural order relation on the natural numbers (i.e., $\langle x, y\rangle \in<$ if and only if $x$ is less than $y$ ), then we write $x<y$ for $\langle x, y\rangle \in<$. [..] Historical Remark. This way of representing relations is essentially due to Hausdorff 1914 who represented ordered relations in a way similar to this one".

34 Cf. also Halmos (1960, pp. 26-27).

35 Enderton (1977, p. 40); Smullyan (1996, p. 23). For a definition of class, cf. Russell (1919, p. 193). For an intuitive distinction between sets and classes, cf. Halmos (1960, pp. 1, 11): "A pack of wolves, a bunch of grapes, or a flock of pigeons are all examples of sets of things. [...] We shall sometimes say collection instead of set. [...] In some approaches to set theory 'class' has a special technical meaning. [...] Some sets are not really sets and even their names must never be mentioned. Some approaches to set theory try to soften the blow by making systematic use of such illegal sets but just not calling them sets; the customary word is 'class'. [...] Roughly speaking, a class may be identified with a condition (sentence), or, rather, with the 'extension' of a condition"; and Enderton (1977, p. 6): "Any collection of sets will be a class. Some collection of sets [...] will be sets. But some collections of sets (such as the collections of all sets not members of themselves) will be too large to allow as sets. These oversize collections will be called proper classes". Or, more formally, Moschovakis (2006, p. 27): "For every unary, definite condition $P$ there exists a class $\mathrm{A}=\{x \mid P(x)\}$ (3.7), such that for every object $x, x \in \mathrm{A} \leftrightarrow P(x)(3.8)$. [...] Every set will be a class, but because of the Russell Paradox [cf. 3.5], there must be classes which are not sets, else (3.8) leads immediately to the Russell Paradox in case $P(x) \leftrightarrow \operatorname{Set}(x) \& x \square x$. [...] By definition, a class is either a set or a unary definite condition which is not coextensive with a set". Cf. also Levy (2004, pp. 7-11) and Russell (1919, pp. 42-51).
} 
domain in $\mathrm{A}$ into $\mathrm{B}(R: \mathrm{A} \mapsto \mathrm{B})$, since the image set of the domain is equal to or a subset of the set of destination. ${ }^{36}$

Now, what could possibly be meant by the qualifier-qualified relation? "A qualifier (viśeșana) [is known as such because it is] in possession of the property qualifier-ness (viśeșaṇatā). [...] In the case of [a cognition such as] 'A blue pot', etc., the property qualifier-ness [finds his limitor] in the property blue-ness. [...] The limitor (avacchedaka) of the qualifier-ness in the qualifier is the qualifier itself. Accordingly, in the example 'A man with a staff', the property staff-hood [operates] as the limitor of [this] qualifier-ness" (NK, pp. 788-789). ${ }^{37}$ In parallel, "it is said qualified (viśișta) a qualificandum (viśeșya) possessing a qualifier (viśeșaṇa). Therefore, a substance (dravya) [e.g., a pot] possessing a quality (guna) [e.g., blueness] is a substance qualified (viśișta) by that quality" (NK, p. 779). ${ }^{38}$ Linking the previous two notions, it could be stated that "a qualified-qualifier cognition (viśișta-viśeșaṇaka-jñana) has as its content (vișaya) a property (vaiśiștya) [occurring] in a subject (dharmin); [in particular, it is a cognition] of a qualificand in possession of a qualificans. So, [e.g.] it is the cognition [concerning] 'A man with a staff'. [...] [In the same way], it becomes evident that the qualifier [i.e. the staff] of a certain qualified [e.g. the man] is [in turn] qualified by another qualifier (viśeșanāntara) [i.e. the staff-hood]. In such a cognition, by virtue of the property qualifier-ness (viśeșanatā), the staff appears as the qualifier on the man's side, and the property staff-hood as the qualifier of the staff. In such a cognition, on the man's side

\footnotetext{
36 Enderton (1977, p. 40): "For example, let $\mathbb{R}$ be the set of all real numbers [...] an suppose that $R \subseteq \mathbb{R} \mathbb{R}$. Then $R$ is a subset of the coordinate plane. The projection of $R$ onto the horizontal plane axis is $\operatorname{dom}(R)$, and the projection onto the vertical axis is $\operatorname{ran}(R)$ ". Smullyan $(1996$, p. 23): "By the domain, $\operatorname{dom}(R)$, of a relation $R$ is meant the class of all $x$ such that $\langle x, y\rangle \in R$ for at least one $y$. By the range of $R, \operatorname{ran}(R)$, is meant the class of all $y$ such that $\langle x, y\rangle \in R$ for at least one $x$. [...] We note that $R \square(\operatorname{dom}(R) \operatorname{ran}(R))$. We say that a relation $R$ is on a class $\mathrm{A}$ if $\operatorname{dom}(R)$ and $\operatorname{ran}(R)$ are both subclasses of $\mathrm{A}$. (This is equivalent to saying that $R$ is a subclass of the Cartesian product A A)". Cf. also Levy (2002, p. 26). Cf. also: Halmos (1960, p. 27): "If $R$ is the relation of marriage, so that $x R y$ means that $x$ is a man, $y$ is a woman, and $x$ and $y$ are married to one another, then $\operatorname{dom}(R)$ is the set of married man and $\operatorname{ran}(R)$ is the set of married women". In referring to relations here, I use a lexicon commonly proper only to functions (mapping, image, etc.) on the account which defines a binary relation as a multi-valued function: "This term [multi-valued function] is generic; it indicates that we are not solely concerned with 'single-valued' functions. In fact, convention forces us to use different terms, following the preoccupations of different authors: we speak of a multi-valued mapping whenever we study properties concerned with linearity or continuity; we speak of a binary relation whenever we study certain structural properties (order, equivalence, etc.); we speak of an oriented graph whenever we study combinatorial properties"; Berge (1963, p. v). Cf. also Berge (1963: ch. II 'Mapping one set into another', $\S 1$ 'Single-valued, semi-single-valued and multi-valued mappings', 20-22): "Let X and $\mathrm{Y}$ be two sets. If with each element $x$ of $\mathrm{X}$ we associate a subset $\Gamma(x)$ of $\mathrm{Y}$, we say that the correspondence $x \rightarrow \Gamma(x)$ is a mapping of $\mathrm{X}$ into Y; the set $\Gamma(x)$ is called the image of $x$ under the mapping $\Gamma^{\prime \prime}$.

37 NK, pp. 788-789: viśeșaṇam-[1] viśeșaṇatāvat | [...] nīlo ghața ity ādau nīlatve viśeșaṇatā $\mid[\ldots]$ viśeșanatāvacchedakam tu viśeșaṇe yad viśeșanam tat | yathā daṇdavān puruṣa ity atra daṇdatvam viśsesanatāvacchedakam iti |. Regarding self-linking relations (svarūpasambandha) and viśeșanatā, cf. Matilal (1968, pp. 40-44): "an absence of something [e.g.] is looked upon as the qualifier of the locus [...]. Nyāya calls such relations relations of qualifier-ness. This is a merely stylistic method Nyāya adopts to describe such a 'supposed' relation without committing itself to the reality of such a relation as a separate entity over and beyond the data". Along the same lines, cf. also Matilal (1968, pp. 69-70, 142).
}

$38 \mathrm{NK}$, p. 779: viśiștam-[1] viśeșaṇavad viśeșyam | yathā dravyam guṇavad ity ādau dravyam guṇaviśiștam $\mid$. 
(āmśa), [the qualifier is] the staff, [but] on the staff side what appears is the staff-ness, by virtue of the relational abstract qualifier-ness: staff-hood must not be conceived on the man's side indeed, because it [only operates] as the limitor (avacchedaka) of qualifierness. It must be understood, in this regard, that a distinct (viśrnkkhala) object of cognition (upasthiti) is the eliciting factor (prayojikā)" (NK, p. 780). ${ }^{39}$ Indeed, man-hood qualifying men is completely independent from staff-hood qualifying staffs. Nevertheless, in the context of this particular qualified-qualifier cognition, staff-hood is the limitor of qualifier-ness, occurring in this particular staff qualifying this man.

And again in NK, "the qualifier-qualified relation (viśeșana-viśeșya-bhāva) is a specific (viśeșa) objectivity (vișayatā). Consequently, in the verbal cognition (śäbdabodha) of [the expression] 'staff holder', the relation qualifier-qualified [itself is the very object of cognition, and that conceived] between staff and man. [...] The qualifier-ness and the qualified-ness, both stand (apanna) in a conditionedconditioner (or restricted-restrictor) relation (nirüpya-nirūpaka-bhāva)" (NK, p. 789). ${ }^{40}$ Although this last sentence may appear straightforward, it deserves a glossa. On the surface - in an initial broad sense which ignores the word-order asymmetry in the text - this could generically refer to the relata mutual dependence within the given relation: which is certainly true, but not very informative. The latter definition (nirüpya-nirüpaka) should thus be taken as a mere rephrasing of the former (viśeșana-viśeșy): the qualifier (viśeșana) is the conditioner or restrictor (nirüpaka) and the qualified (viśesya) is what is conditioned or restricted (nirüpya). Taking more seriously the inversion of the word-order symmetry in NK text (nirüpya-nirüpaka vs. viśeșana-viśesya), however, the extended copulative structure (ca) and abstracting forms (-tva), there is also a potential second sense: both qualifier-ness and qualifiedness could equally and complementary acquire the status of conditioner or conditioned. The first case has already been discussed: the qualifier is the conditioner and the qualified is the conditioned. The second appears much more striking, however: the qualifier would be the conditioned and the qualified the conditioner.

\footnotetext{
${ }^{39} \mathrm{NK}$, p. 780: viśișta-viśeșanaka-jñānam-[1] viśeșanavadviśeșyasya dharmiṇi vaiśiștyavișayakam jñānam | yathā danḍavān puruṣah iti jñānam | [...] [2] kvacit viśeșye yad viśseșanam tatrāpi viśeșan̄āntaram iti rītyā jāyamānam jñānam bhavati | yathā dandavān purușah iti jñānam | atra jñāne

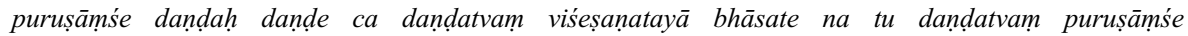
viśeșanatāvacchedakatayā bhāsate | atra viśrnikhalopasthitih prayojikā iti vijñeyam |. Cf. NK, p. 784. viśrńnkhalatvam-pārthakyam; 'severalty'. Cf. also NK, p. $175 . \quad$ upasthitih-[1] buddhivadasyärthonusamdheyah| [2] smrtih [...]|; 'The object of the cognitive discourse. Recollection'.

${ }^{40}$ NK, p. 789: viśeșana-viśeșya-bhāvah-[...] [2] vișayatāviśeșah | yathā daṇ̣̂̄ purușah iti śäbdabodhe dandapurușayor viśeșanaviśeșyabhāvah | atra vigrahah viśeșanam ca viśeșam ca viśeșanaviśesye | tayor bhāvah iti ('The analysis [of the compound] qualifier-qualified [here reads]: qualifier and qualified [i.e., it is a dvandva, a copulative compound]'. [This is] their relation') | nirüpyanirūpakabhāvāpannam viśeșanatvam viśeșyatvam cety arthah |. Cf. Gadādhara (1990: II, 78): "XIV. viśeșyatāprakāratāvat samsargatvasyāpi vișayatāviśeșātmakatvāt, samssargasyāpi viśișțadhīvișayatvam \|. Translation: Like qualificandumness [viśeșatā] and qualifierness [prakāratā] the qualificationness [samsargatva; i.e. the property of being a relation of qualification], too, is a special kind of objectivity; hence, the qualification [samsarga], too, has the objectivity of qualified cognition. Explanation: The object of qualified cognition is a relational complex having three elements-a qualificandum, a qualifier and a relation between them. Now, since the entire relational complex is what is cognized, and, according to Nyāya, the relational complex is not an ontological entity over and above the three elements, all three of the elements have to be accorded a different type of objectivity". Square brackets are mine. Cf. also, NK, p. 935, samsargah-1 [ka] sambandhah $\mid$. Regarding the notion of 'restriction' cf. Anrò (forthcoming: § 3.2).
} 
Thereby, in the context of a qualifier-qualified relation, the qualifier could be conceived as what is conditioned, thereby becoming a conditioned qualifier; and the qualified as the conditioner or restrictor, acting as a qualified conditioner (or conditioning qualified)—paradoxical though it may sound (cf., end of $\S 4$.). ${ }^{41}$

\section{Relations in NL \& the Colocated Qualification Principle (SVN)}

We can now return to the case of the golden crown. Following the NL formalisation method, let crown-hood (mukutatva, $m_{t}$ ) be the root-property (mukhya-viśeșana; cf. supra), for $\left|m_{t}\right|=\mathrm{M}$ and $m \in \mathrm{M}$; and gold-ness (hätakatva, $h_{t}$ ) a second-level colocated property, for $\left|h_{t}\right|=\mathrm{H}$ and $h \in \mathrm{H}$. Furthermore, let $\boldsymbol{N}$ (italic bold capital) be the relational abstract 'coreferentiality' (sāmānādhikaranyatā) referring to the binary relation $N$ (italic capital; sāmānādhikaranya, 'coreference' or 'syntactic homogeneity'). ${ }^{42}$ In parallel, be $\boldsymbol{V}$ (viśeșya-viśeșaṇa-samsargatā, or viśeșanatā) the relational abstract of relation $V$ (viśeșya-viśeșana-bhāva-sambandha), the relation qualifier-qualificand as viśișta-jñ̄ana (cf. supra). Let ' '’ (top left corner) be the avacchedaka operator, so that ' $b+$ top left corner + relational abstract' (i.e., $b\urcorner \boldsymbol{R}$ ) would mean ' $b$ operates as the avacchedaka of the relational abstract $\boldsymbol{R}$ ' (for $\langle a, b\rangle \in R$ ). In parallel, be ' $\llcorner$ ' (bottom right corner) the nirüpaka operator, so that 'relational abstract+bottom right corner $+a$ ' (i.e., $\boldsymbol{R}\llcorner a$ ) would mean ' $a$ is the nirüpaka of $\boldsymbol{R}$ '. A basic relation would thus appear in NL as: $b\urcorner \boldsymbol{R}\llcorner a$, 'The relation $R$ is conditioned by $a$ (the relational adjunct, or pratiyogin) and limited by $b$ (the relational subjunct, or anuyogin)'. We are now in a condition to analyse the assertion 'mukuțạ hătakam' ('A golden crown' $)^{43}$ in NL as:

\footnotetext{
${ }^{41}$ Cf. NK, p. 432: nirūpyatvam-nirūpitatvam |. NK, p. 432. nirūpitatvam-svarūpasambandhaviśeșah $\mid$ yathā rājñah puruṣa ity adau purușanișthasvatve rājanișthasvāmitvanirūpitatvam | śiștam tu nirūpakatvaśabde drasțavyam |. 'The property of being conditioned (or restricted) is a peculiar self-linking relation. In sentences such as 'The servant of the king', the property of being conditioned by the ownership (svāmitva) occurring in the king [must be sought] in the possess-ness (svatva) occurring in the man. What remains must be seen sub voce nirüpakatva (being a conditioner)'. In this example, the qualifier (the ownership occurring in the king) is also the conditioner, precisely because the property of being conditioned (i.e. the qualified-ness) of the qualified (the possess-ness occurring in the man) is in question here. However, the relation could easily be reversed: the qualifier-ness occurring in the qualifier (the ownership occurring in the king) could be conditioned (nirüpita) by the qualified-ness occurring in the qualified (the possess-ness occurring in the man), which consequently becomes the conditioner. QED.

${ }^{42}$ For a discussion of ordered pairs formalisation (albeit limited to vrtti-niyāmaka relations only), cf. also Staal (1973, p. 152 ff). In his plain notation: $A$ (x, y). Cf. also Bhattacharyya (1987, p. 174): "To distinguish this sense of 'property' $[\ldots]$, we shall write 'property $(\mathrm{N}-\mathrm{N})$ "'.

${ }^{43}$ For the purposes of this analysis, it is not paramount whether the description is definite or indefinite; let us assume here that it is indefinite and non-generic: 'A golden crown', expressed by $m$ as a primitive term. For these particular examples, cf. Ganeri (2006, pp. 10-11). Cf. also Matilal (1968, § 9.7, 78-79); Ingalls (1951, p. 50): "Navya-Nyāya regularly expresses its universal statements and knowledges not by quantification but by means of abstract properties"; Ganeri (2008, pp. 110, 118): "The Nyāya authors themselves do not [...] show much interest in the problems of scope ambiguity [...]. And often the language is used in only a semiformal way, especially when used by non-Nyāya authors". Russell (1919, pp. 167-180): "An indefinite description is a phrase of the form 'a so-and-so', and a definite description is a phrase of the form 'the so-and-so' (in the singular)". For a complete introductory survey of generic (or definite) and generic (or non-generic) descriptions, cf. Ludlow (2018).
} 
[2] $h . \stackrel{N}{N}\llcorner m$

yā sāmānādhikaranyatā hātaka-nișthā sā mukuṭa-nirūpitā; 'The relational abstract of coreferentiality or syntactic homogeneity, conditioned (nirūpita) by a crown $(m)$, occurs (niștha) in an instance of gold ( $h$; viz., it refers to this gold as its locus)'; iff $h \in\left(\left|h_{t}\right|=\mathrm{H}\right)$ ('Being an instance of the property gold-ness, a specimen of gold belongs to the set What is golden, that is, the set Gold'), $m \in$ $\left(\left|m_{t}\right|=\mathrm{M}\right)$ ('Being an instance of the property crown-ness, a crown belongs to the set Crowns'), $(h \in \mid \boldsymbol{N}\llcorner m \mid)$ ('A specimen of gold belongs to the set What is coreferential with a crown'), that is, $\langle m, h\rangle \in N$ ('A crown and an instance of gold are an ordered couple belonging to the relation $x$ is coreferential/ syntactically homogeneous to $y$ '). In standard notation: $(\exists x)(\mathrm{H} x \wedge \mathrm{M} x)$ ('There do exist an $x$ which is gold and a crown'), for $\mathrm{H} \cap \mathrm{M} \neq \varnothing$ ('The intersection of the set Gold and the set Crown is not empty').

Be noted here the niștha operator ('.'; a dot instead of ' $\urcorner$ '), connecting a property with a primitive term conceived as its locus. ${ }^{44}$ The relation [2] can then be further specified, for $\mathrm{TvN}$, as:

$$
\left.\left[2_{\mathrm{a}}\right]\left(h \cdot h_{t}\right)\right\urcorner \boldsymbol{N}\left\llcorner\left(m \cdot m_{t}\right)\right.
$$

yā sāmānādhikaranyatā hāṭaka-niṣtha-hāțakatvāvacchinnā sā mukuṭa-niṣthamukutatva-nirüpitā; 'The relational abstract of coreferentiality, conditioned by the property crown-hood referring to a crown, is limited (avacchinna) ${ }^{45}$ by the property gold-ness occurring in an instance of gold'- the purport (tätparya,

\footnotetext{
${ }^{44}$ Regarding the niștha operator, cf. Anrò (forthcoming). A primitive term is always on the operator's left side, while a property is always on its right. Thereby, for a generic primitive term 'a' and a generic property ' $\mathrm{a}_{t}$ ', the expression ' $a$. $a_{t}$ ' will mean ' $a$-hood occurring in $a$ '.

${ }^{45}$ Ganeri $(2008$, pp. 109, 115): "So a conditioner maps to an existential quantifier, whose domain is restricted to the class assigned to the conditioner, and which binds the second place of a dyadic predicate. Similarly, a delimitor maps to a universal quantifier, whose domain is restricted to the class assigned to it, and which binds the first place of a dyadic predicate. [...] The universal quantifier corresponding to the limitor always has wider scope than the existential quantifier corresponding to the conditioner". Cf. also Ingalls (1951, p. 48): "The relational abstracts [...] are limited by the qualifiers of the entities in which they reside. Technically these abstract are said to be limited through a relation of residency (nișthatvasambandhāvacchinna; cf. Śiv. Miśra, 22.8)". Ingalls (1951, p. 49): "No one method can be followed for reducing expressions employing 'limited' to the terms of Western logic".
} 
henceforward $\left.{ }^{(t)}\right)$ of which is ${ }^{(t)}$ Gold-ness in a specimen of gold occurring in a crown qua instance of crown-hood'.

The relation $\left[2_{\mathrm{a}}\right.$ ] can now be interpreted and rephrased in terms of the qualifierqualified relation $(V)$. The crown is $(N)$ gold because it is qualified $(V)$ by gold:

[3] $\left.\left(h . h_{t}\right)\right\urcorner \boldsymbol{V}^{(N)}\left\llcorner\left(m . m_{t}\right)\right.$

yā viśeșaṇatā hātaka-niștha-hāțakatvāvacchinnā sā mukuṭa-niștha-mukuțatvanirūpitā; "The relational abstract qualifier-ness, conditioned by the property crown-hood, referring to a crown, is limited by the property gold-ness occurring in an instance of gold'. Iff $h \in\left(\left|h_{t}\right|=\mathrm{H}\right) ; m \in\left(\left|m_{t}\right|=\mathrm{M}\right) ; h \in \mid \boldsymbol{V}^{(\mathrm{N})}\llcorner m \mid$ ('A specimen of gold belongs to the set [Coreferential] Qualifiers of a crown'). ${ }^{46}$ Note here $V^{(N)}$, that is, ' $N$ interpreted as $V$, salva veritate'.

The root property crown-hood (mukutatva, $m_{t}$ ) - adjunct of the relational abstract $\boldsymbol{V}^{(N)}(\boldsymbol{N}$ as $\boldsymbol{V})$ - binds the dominion of the relation to $\mathrm{M}$ (the set Crowns), thereby effectively ruling out the complement set of $\mathrm{M}$ (i.e. $\bar{M}$, the set Everything which is not a crown). Consequently, if coordination [a] is true for $\mathrm{M} \cap \mathrm{H} \neq \varnothing$, relation [3] from the set of departure $\mathrm{M}$ de facto excludes possibilities [b] and [c]. In other words, it obliterates $\overline{\mathrm{M}}$-consequently, $\mathrm{H} \cap \overline{\mathrm{M}}$ as well, viz. 'Everything which is gold but not a crown' - and it is true for $\mathrm{H}^{\operatorname{sub}[3]} \subseteq V^{(N)}[\mathrm{M}]$ (i.e., given [3], we are dealing only with gold coreferential to crowns; for $\operatorname{dom} V^{(N)} \subseteq \mathrm{M}$ and $\left.\operatorname{ran} V^{(N)} \subseteq V^{(N)}[\mathrm{M}]\right)$. Stemming from the fact that we are talking about the properties of a crown, gold-ness ends up being gold-ness in crowns and thereby included in the set Coreferential properties of crown-ness $\left(V^{(N)}[\mathrm{M}]\right){ }^{47}$

\footnotetext{
${ }^{46}$ Obviously, different formulations would have been possible. For instance, in terms of 'specification' (or distinguishing property): vaiśistya, whose relational abstract will be vaiśiștyatva. Or in terms of 'qualified-ness' (viśesyatā), conceived as the converse of the relation qualifier-ness (viśeșanatā): thereby, $V$

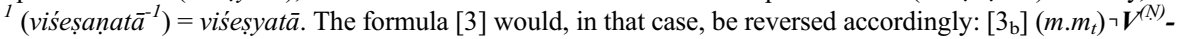
$1\left\llcorner\left(h . h_{t}\right) ; y \bar{a}\right.$ mukuṭa-niștha-mukutatvāvacchinnā sā häțaka-niștha-häțakatva-nirūpita-viśeșyatā, 'Qualifiedness, with respect to gold-ness in an instance of gold, is referred to crown-ness occurring in a crown'. Cf. NK, p. 812; vaisisistyam - 1[ka] saṃbandhah | yathā bhütalam ghațaviśiștam ity àdau ghațabhūtalayoh samyoganāma a sambandho vaisisistyam |; "Specification is a relation, according to which, in [expressions] such as 'The ground qualified by a pot', the relation named as 'contact', between pot and ground, is implied". Cf. also: Staal (1988, p. 62). Regarding the converse: Schmidt (2011, p. 39): "Definition 4.2. Given a relation $R$ : $\mathrm{X} \mapsto \mathrm{Y}$, its converse (or transpose) $R^{\mathrm{T}}: \mathrm{Y} \mapsto \mathrm{X}$ is that relation in the opposite direction in which for all $x, y$ containment $\langle y, x\rangle R^{\mathrm{T}}$ holds precisely when $\langle x, y\rangle R^{\prime \prime}$. Regarding the transpose, inverse, or converse, see, among others: Bourbaki II.3.2 (1968, p. 78); Jech (2006, p. 11); Berg (1997, p. 24); Enderton (1977, pp. 44-46); Russell (1919, pp. 16, 32, 42-49). In relation to converse in NL, cf. Anrò (forthcoming).

${ }^{47}$ Cf. Ingalls (1951, p. 50): nirüpitatva-sambandhenāvacchinna, an abstract "limited through a relation of described-ness". Since the specific case of the qualified-qualifier binary relation $\left(V^{(N)}\right)$ has as a rule of assignment 'The crown $(m)$ is qualified by gold $(h)$ ' or $\langle m, h\rangle V^{(N)}$, it is worth underlining the inversion occurring in [2] and [3] between the two relata: the abstract property $\boldsymbol{V}^{(N)}$, or the property to qualify the crown, is in gold not in crown. Consequently, it is the crown that is qualified.
} 
Since it concerns a pair of coreferential (samānādhikarana) locatees occurring in the very same locus, relation [3] is describable by what I will hereafter call Samānādhikarana-Viśiștatva-Nyāya (SVN, 'Principle of Coreferential Qualification'). In case of coreference, SVN, following a strictly relational logic, can bind all further properties to a chief or root one (mukhya-viśeșana). According to SVN, the qualifier (viśeșana) corresponds - under the condition of relation $V^{(N)}$ - to the image of the qualificandum (viśesya); this is in turn already qualified (i.e. it is a crown and not a bucket) and alone defines, as the root-property, the relational dominion. Thereby, gold-ness ${ }^{\mathrm{sub}[3]}$ ends up being a subset of properties of crowns because, having considered the viśeșa primarily as a crown, no further cognition can avoid this basic qualification any longer. The qualificans gold-ness, occurring in the qualifier and referring to a crown, corresponds to the image of crown-hood under relation $V^{(N)}$, which consequently has as its elements the instances of gold-ness solely in crowns because it is conditioned by crown-ness $\left(h_{t}\right\urcorner \boldsymbol{V}^{(N)}$, hätakatvāvacchinnaviśeșanatā, 'Gold-ness as qualifier' — as a consequence, we are not primarily talking about gold, which is only what qualifies something else; $\boldsymbol{V}^{(N)}\left\llcorner m_{t}\right.$, mukutatvanirüpita-viśeșanatā, 'Crown-hood as qualified', that is, what we are talking about). It goes without saying that SVN applies only in coreference cases (i.e. $N$ as $V$ ). If a blue pot is a pot ( $N$ as $V$ ), a man with a stick is not a stick ( $V$ only) - even though the man is qualified by his stick.

A relation can be grasped more effectively if topologically displayed in a Cartesian coordinate system. Ordered pairs on the plane make pictorially evident the fact that the first and foremost concern of Nyāya account is relations. To provide a first example, be given a general relation different from $V$. Let $L$ be the relation 'locus of' and $\boldsymbol{L}$ its relational abstract 'locus-hood' (āśrayatā). An instance of smoke $(d$, dhüma) on a mountain ( $p$, parvata) could be thus expressed in NL as: $p$. $\boldsymbol{L}\llcorner d, y \bar{a}$ āśrayatā parvata-nișthā sā dhūma-nirūpitā, true for $p \in \mid \boldsymbol{L}\llcorner d \mid$, viz. 'A mountain belongs to the set Loci of an instance of smoke'. Because the relation is $\langle p, d\rangle \in L$ (or ' $p$ is the locus of $d$ '), it follows that on the Cartesian plane $L$ identifies the ordered pair 'smoke' (in abscissa) and 'mountain' (in ordinate). This latter is a member of the set 'Loci of a smoke' along with e.g. 'a portion of space', 'a fire', etc. Mountain and smoke are obviously distinct objects, with different qualifying properties (for TvN) and different reference sets. Nevertheless, bound by the relation 'locus of' under the condition 'smoke', this mountain ends up belonging to the set 'Loci of a certain smoke'. This implies that the main element of interest is neither the mountain nor the smoke. As topologically made evident in the Cartesian plane, what is at stake here is the property locus-hood with respect to smoke; a property occurring in this mountain along with others that are completely different in nature (e.g. 'a fire'). Clearly, SVN cannot apply.

Let us now focus on the specific relation $N$ as $V$. So, let be in abscissa the set 'Triangles' (T) and in ordinates the set 'Coreferential properties of triangles' $\left(V^{(N)}[\mathrm{T}]\right)$. This latter includes all the properties referable to triangles, such as 'having 
the sum of internal angles equal to $180^{\circ},\left(p_{1}\right)$, 'possessing a right angle' $\left(p_{2}\right)$, 'possessing equal sides' $\left(p_{3}\right)$, etc. (i.e., $\left.p_{1}, \ldots \ldots, p_{n}\right)$. If $p_{1}$ is a property possessed by all instances of triangles, $p_{3}$ (itself a subset of the set in ordinates) it will on the contrary be referable only to a subset of $\mathrm{T}$ in abscissa: by definition, referable only to equilateral triangles. Thereby the relation $\left\langle t, p_{3}\right\rangle \in V^{(N)}$ (' $t$ is qualified by $p_{3}$ ', for $V^{(N)} \subseteq \mathrm{T} V^{(N)}[\mathrm{T}]$ ) will define the portion of the plane identifying equilateral triangles. The dominion of the relation plainly claims that only triangles are under discussion here: an equilateral triangle-qualified via $\left\langle t, p_{3}\right\rangle \in V^{(N)}$-is but a triangle, for: $\left(\operatorname{dom} V^{(N)} \subseteq \mathrm{T}\right) \wedge\left(\left|p_{3}^{\text {sub_dom } V(N)}\right| \subseteq V^{(N)}[\mathrm{T}]\right) .^{48}$ However, $N$ as $V$ by definition imposes that $V^{(N)}[\mathrm{T}]$ refer to $\mathrm{T}$; consequently, both $\operatorname{dom} V^{(N)}$ and $\operatorname{ran} V^{(N)}$ are equal to or a subset of $\mathrm{T}$, for $V^{(N)}: \mathrm{T} \mapsto V^{(N)}[\mathrm{T}]$ and $V^{(N)}[\mathrm{T}] \subseteq \mathrm{T}$. In general, "for a relation $R$, a class $\mathrm{A}$ is said to be $R$-closed, or closed under $R$, if whenever $x \in \mathrm{A}$ and $x R y$ then also $y \in$ A (i.e., $R[\mathrm{~A}] \subseteq \mathrm{A}$ )" (Levy 1979, p. 61). Therefore, the relation $N$ as $V$ under examination is revealed to be an instance of closure: the set Coreferential properties of triangles is T-closed under the relation $N$ as $V^{49}$

The same applies to the case of golden crowns and blue pots. Indeed, the relation is presented as ordered pairs with crowns or pots in abscissa (for M, the set Crowns; and $\mathrm{G}$, the set Pots), and Properties of crowns or Properties of pots in ordinate. It follows that in [3]: $\left(h \in\left(\left|h_{t}\right|=\mathrm{H}\right)\right) \in \mid \boldsymbol{V}^{(N)}\llcorner m \mid$, i.e. an instance of the property goldness belongs to the set What qualifies a crown (or Properties of a crown) - along with many others, such as heaviness, brightness, etc. The set $\mathrm{H}^{\mathrm{sub}[3]}$ (qua $\mathrm{H}^{\mathrm{sub}[3]} \subseteq$ $V^{(N)}[\mathrm{M}]$ ) is thus M-closed under the formula [3], for $V^{(N)}[\mathrm{M}] \subseteq \mathrm{M}$. The relation $N$ as $V$ is in fact a mapping of $\mathrm{M}$ (for $\operatorname{dom} V^{(N)} \subseteq \mathrm{M}$, the set Crowns as set of departure) onto the set Properties of crowns (for $\operatorname{ran} V^{(N)} \subseteq V^{(N)}[\mathrm{M}]$, the set of destination); that is, $V^{(N)}: \mathrm{M} \mapsto V^{(N)}[\mathrm{M}]$. In other words, the relation $N$ as $V$ defines the image of Crowns in Properties of crowns through the medium of a particular property, here gold-ness; for this reason, the property gold-ness ${ }^{\text {sub[3] }}$ is but a sub-set of Properties of crowns. Clearly, the properties involved-gold-ness and crown-ness-are reciprocally unrelated (viśrnikhala) (cf. fn. 39) because the former is certainly not a subset of the latter; at most, the intersection of their two domains might be non-empty. However, here hattakatva plays the role of coreferential viśeșana (qualifier) of a particular viśesya (qualified), in turn qualified by the property mukutatva - and this root-qualification cannot simply be dismissed. A golden crown is a crown because the viśeșa itself (the crown) in relation $N$ as $V$ is already qualified by crown-hood:

\footnotetext{
${ }^{48}$ For $\left|p_{3}^{\text {sub_dom } V(N)}\right|=$ 'The extension of the property being equilateral under the condition imposed by the relational domain of $V^{(N)}$ relation (in this case, Triangles)'. It goes without saying that all squares, equilateral pentagons, etc., are immediately ruled out by definition.

${ }^{49}$ Cf. Smullyan (1996, p. 132): "The Henkin closure condition. Given a subset B of A and a formula $\varphi$ whose constants are all in $\mathrm{B}$, we shall say that B is A-closed with respect to $\varphi$ if for every subformula of $\varphi$ the form $(\exists x)\left(x, y_{1}, \ldots, y_{n}\right)$ (where the free variables of $\psi$ are $\left.x, y_{1}, \ldots, y_{n}\right)$ and for all element of $b_{1}, \ldots, b_{n}$ of $\mathrm{B}$, if there is some element $a$ of A such that the sentence $\left(a, b_{1}, \ldots \ldots, b_{n}\right)$ is true over A, then there is some $b$ in B such that $\psi\left(b_{1}, \ldots, b_{n}\right)$ is true over A". Cf. also Bourbaki III.1 ex. 13 (1968, pp. 216-217); Enderton (1977, p. 78); Berge (1997, p. 12); Schmidt (2010, pp. 169-170). It goes without saying that the first example - regarding the loci of smoke $\left(\mid \boldsymbol{L}\left\llcorner d_{t} \mid=L[\mathrm{D}]\right)\right.$-implying the relation $L$ is not a case of closure. Because, if $L$ : $\mathrm{D} \mapsto L[\mathrm{D}]$ and therefore a mountain belongs to the set Loci of smoke, $p \in \mid \boldsymbol{L}\left\llcorner d_{t} \mid\right.$ or $p \in L[\mathrm{D}]$, still, $L[\mathrm{D}]) \subseteq$ D; i.e. the Loci of smoke are not a subset of Smoke, unlike Blue pots which are clearly a subset of Pots.
} 
SVN in [3] identifies gold-ness as a property occurring in a crown-precisely, a golden one-and not the set of all golden things. For the same reason 'A blue pot is a pot'.

Let us now proceed by adopting a different approach to demonstrate SVN in terms of limiting properties only (avacchedaka). It has been shown (cf. fn. 47) that the $\boldsymbol{V}$-relational subjunct (viśeșanatā-samsargīya-anuyogin, a) or limitor ( $v\urcorner \boldsymbol{V}$, viśeșan̄âvacchinna-viśeșanatā) is always the $V$-qualifier (viśeșaṇa, $v$; thus: $v=$ a) because it is what expresses the quality (viśeșa). In the example, gold-ness in gold is the $\boldsymbol{V}$-limitor. It should be recalled that the relational abstract $\boldsymbol{V}$ reverses the terms of relation $V$ (i.e. $\langle v i s ́ e s ̦ y$, viśeșana $\rangle \in V$; or in short and for $v^{-1}=v i s ́ e s ̦ a:\left\langle v^{-1}, v\right\rangle \in V$ ), making explicit the fact that $\boldsymbol{V}$ refers to the viśeșana only under the condition of the viśesya. $^{50}$ In the case of a golden crown $(N$ as $V)$, gold-ness in gold is the qualifier (v) of a crown $\left(v^{-1}\right)$ : mukuṭa-viśeșanam hạtaka-niștha-hātakatvam. Thereby, hātakatvāvacchinna-viśeșanatā, 'The qualifier-ness $\left(\boldsymbol{V}^{(N)}\right)$ is limited by gold-ness' (cf. $v\urcorner V$ ). In general:

[4] $v\urcorner \boldsymbol{V}^{(N)}\left\llcorner v^{-1}\right.$

yā samānādhikaraṇa-viśeșaṇatā viśeșaṇāvacchinnā sā viśeșya-nirūpitā; 'Coreferential $(N)$ qualifier-hood $\left(\boldsymbol{V}^{(N)}\right)$, conditioned by the qualified $\left(v^{-l}\right)$, is limited by the qualifier $(v)$ '.

As a general scheme, 'The relational abstract subjunct-ness $(\boldsymbol{A})$, limited by the relational subjunct $(a)$, is limited by the relational abstract coreferential qualifier-ness $\left(\boldsymbol{V}^{(N)}\right)$ limited by the qualifier $(v)$, expressing the ascribed quality (viśeșa; e.g. goldness in gold)', that is:

\footnotetext{
${ }^{50}$ Let us recall that what we are dealing with here is the sentence hătakam mukutam, 'The crown (subject qualified) is gold (qualifying property, or qualifier)'. What we are talking about are thus crowns, and we are attributing to them a particular quality (e.g. gold-ness). Therefore, the property 'being a qualifying property' (or 'being a qualifier', viz. 'qualifier-ness') obviously lies in gold-ness, and it is precisely here the inversion occurs: because now, shifting from crowns to gold, we are dealing with gold-ness and its qualifying power. This pattern can be found in every instance of qualification: dandị purușah, 'Staff holder'; vahnivān parvatah (and all its permutation: e.g. savahnir parvatah, etc.), 'A mountain with fire'; meghadütah, 'Cloud messenger'; etc. Syntactical permutations often found in common expressions-e.g. parvate vahnih, 'Fire on a mountain' - merely confirm the schema: in this case fire is the qualified, while mountain is the qualifying item. Therefore, the property qualifier-ness here refers to mountain. The superscript $\left(x^{-1}\right)$ points out the transpose of the base $(x)$; cf. supra fn. 46 .
} 
[5] $\left.\left.v\urcorner \boldsymbol{V}^{(N)}\right\urcorner a\right\urcorner \boldsymbol{A}$

viśeșaṇa-avacchinna-samānādhikaraṇa-viśeșaṇatā-avacchedaka-avacchinnaanuyogy-avacchinna-samsargīyānuyogitā. More straightforwardly: (t)‘ The qualifier $(v)$ is always the relational subjunct $(a)$ in $\boldsymbol{V}^{(N)}, 51$

Conversely, the relational pratiyogin $\left(a^{-1}\right.$; i.e. the qualified, viśesya, $\left.v^{-1}\right)$ operates in $\boldsymbol{V}^{(\mathrm{N})}$ as a dominion conditioner (nirūpaka): mukuțatva-nirūpitam hātaka-niștha-hātakatvam, 'Gold-ness in gold conditioned (i.e., under the dominion restriction imposed) by crownness'. At the same time, the crown is the qualified which is qualified by gold-ness: hățakatvena viśiștam viśeșyam mukuțam. And yet the viśeșya $\left(v^{-1}\right)$-being that which is qualified, as well as the adjunct (pratiyogin) and conditioner (nirüpaka) in $\boldsymbol{V}^{(N)}$ (cf. [4]) - is in $N$ as $V$ (cf. supra: $\left\langle v^{-1}, v\right\rangle V^{(N)}$ ) the limitor (avacchedaka) of the attributed property (viśeșa, $s$ ). Indeed, the property occurs in what is qualified: $\left.v^{-1}\right\urcorner s^{\prime}$, viśeșyāvacchinna-viśeșah ('The quality limited by the qualified'). What does goldness refer to? The only viable answer is obviously the crown. Thus: $\left.m_{t}\right\urcorner h_{t}$, mukuțatvāvacchinna-hātakatvam. In general, substituting [4] and [5] in $\left\langle v^{-1}, v\right\rangle V^{(N)}$ :

$\left.\left.\left.\left.\left.\left.[6]\left\langle\left(v^{-1}\right\urcorner \boldsymbol{V}^{(N)-\boldsymbol{I}}\right\urcorner a^{-1}\right\urcorner \boldsymbol{A}^{-\boldsymbol{I}}\right),(v\urcorner \boldsymbol{V}^{(N)}\right\urcorner a\right\urcorner \boldsymbol{A}\right)\right\rangle \in V^{(N)}$

viśeṣaṇa-avacchinna-samānādhikaraṇa-viśeșaṇatā-avacchedaka-avacchinnaanuyogy-avacchinna-sam sargīyānuyogitā-viśișta-viśesya-avacchinna-samānādhikarana-viśeșyatā-avacchedaka-avacchinna-pratiyogy-avacchinna-samsargīya-pratiyogitā; 'The relational abstract adjunct-ness $\left(\boldsymbol{A}^{-\boldsymbol{I}}\right)$, limited by the relational adjunct $\left(a^{-1}\right)$, is limited by the relational abstract coreferential qualified-ness $\left(\boldsymbol{V}^{(N)-1}\right)$ limited by what is qualified $\left(v^{-1}\right)$; this compound is in turn qualified (viśișta; in bold) by relational abstract subjunct-ness $(\boldsymbol{A})$, limited by the subjunct $(a)$, limited by the relational abstract coreferential qualifier-ness $\left(\boldsymbol{V}^{(N)}\right)$ limited by the qualifier $(v),{ }^{52}$

\footnotetext{
51 Formula [5] speaks about a specific kind of relatum: that relatum which: (1) is a limitor (anuyogin) and (2) is involved in a qualified-qualifier relation. In this sense, the generic relational abstract subjunct-ness (samsargīyānuyogitā, $\boldsymbol{A}$ ) is limited (avacchinna) by qualifier-ness (viśeșanatā, $\boldsymbol{V}$ ), thereby becoming a specific subjunct-ness: the subjunct-ness concerning qualifier-ness. If the formula had been inverted (i.e. $a\urcorner \boldsymbol{A}\urcorner v\urcorner \boldsymbol{V}$ ), it would have been about the 'property of being a qualifier' occurring in an anuyogin. That makes perfect sense, but it is not the 'property of being an anuyogin' occurring in the qualifier, which is instead the case at stake here. See Shaw (1989, p. 383): "Since $a$ is the first term of the relation $R$ and $b$ is the second term, $a$ has the property of being the first term and $b$ has the property of being the second term. Hence corresponding to every relation the Nyāya recognises two relational abstract properties such that one of them resides in the first term and the other one resides in the second term"; and also Shaw (2010, p. 627).

52 It is worth noting that formulas such as [2], [3], or [4] could be called ' $N L$ relational formulas' (NL-RF, or simply RF). In these cases, a well formed formula contains a relational abstract in its central position, between the operators nirüpaka (' $\llcorner$ ', on right side; consequently: avacchinna, 'limited') and avacchedaka (' $\urcorner$ ', on right side): as suggested above, if $\langle a, b\rangle R$, then $b\urcorner \boldsymbol{R}\llcorner a$. Here, the relational abstracts pratiyogit $\bar{a}$ and anuyogitā do not have to be - or, better, must not be - expressed because they are already embedded in the formula's positional order. On the contrary, expressions such as [7] are not relations, but descriptionswhich could be called 'NL avacchinna-avacchedaka descriptions' (NL-AAD, or simply AAD). A wellformed $\mathrm{AAD}$ reads no central relation but rather a string of limitors and limited. In these cases, the relational abstracts pratiyogitā and anuyogitā — referring to the corresponding RF — could be made explicit. For a discussion of well-formed formulas, RF, and AAD, cf. Anrò (forthcoming).
} 
Roughly speaking, if ' $x$ is qualified by $y$ ' $\left(\langle x, y\rangle \in V^{(N)}\right)$, what is $x$ ? The pratiyogita in the pratiyogin occurring in the qualified-ness in the qualified. And what is $y$ ? The anuyogitā in the anuyogin occurring in the qualifier-ness in the qualifier. However, it has been shown that the qualifying property $\left(s^{\prime}\right)$ occurs in the qualified $\left.\left(v^{-1}\right\urcorner s^{\prime}\right)$ and it goes without saying that the qualifying property is nothing but the qualifier $(v=s)$; thus, in composing the above partial formulas, we can bring together [4] and [6] in a description such as [7]:

[7] $\left.\left.\left.\left.\left.\left.\left.v^{-1}\right\urcorner \boldsymbol{V}^{(N)-1}\right\urcorner a^{-1}\right\urcorner \boldsymbol{A}^{-\boldsymbol{1}}\right\urcorner v\right\urcorner \boldsymbol{V}^{(N)}\right\urcorner a\right\urcorner \boldsymbol{A}$

viśeșya-avacchinna-samānādhikarana-viśeșyatā-avacchedaka-avacchinna-

pratiyogy-avacchinna-samsargīya-pratiyogitā-avacchinna-viśeșaṇa-avacchinna-samānādhikaraṇa-viśeșaṇatā-avacchedaka-avacchinna-anuyogy-avacchinna-samsargīyānuyogitā; 'The relational abstract subjunct-ness $(\boldsymbol{A})$, limited by the subjunct $(a)$, limited by the relational abstract coreferential qualifierness $\left(\boldsymbol{V}^{(N)}\right)$ limited by the qualifier $(v)$, whose limitor is the relational abstract adjunct-ness $\left(\boldsymbol{A}^{-1}\right)$, limited by the relational adjunct $\left(a^{-1}\right)$, limited by the relational abstract coreferential qualified-ness $\left(\boldsymbol{V}^{(N)-1}\right)$ limited by what is qualified $\left(v^{-1}\right)$ '. Roughly speaking, ${ }^{(\mathrm{t})}$ 'That which is the anuyogin in $\boldsymbol{V}^{(N)}$ (i.e. the qualifier) occurs in the pratiyogin (i.e. the qualified).

In light of the above, however, given [3] $\left.h . h_{t}\right\urcorner \boldsymbol{V}^{(N)}\left\llcorner m . m_{t}\right.$ (implying $m_{t}=v^{-1}$ and $h_{t}$ $=v)$, then:

$\left.\left.\left.\left.\left.\left.\left.\left[7_{\mathrm{a}}\right] m . m_{t}\right\urcorner \boldsymbol{V}^{(N)-1}\right\urcorner a^{-1}\right\urcorner \boldsymbol{A}^{-\boldsymbol{1}}\right\urcorner h_{t}\right\urcorner \boldsymbol{V}^{(N)}\right\urcorner a\right\urcorner \boldsymbol{A}$

mukuṭa-niștha-mukuțatva-avacchinna-samānādhikaraṇa-viśeșyatā-avacchedaka-avacchinna-pratiyogy-avacchinna-samsargīya-pratiyogitā-avacchedakaavacchinna-hātakatva-avacchedaka-avacchinna-samānādhikaraṇa-viśeșaṇatā-avacchedaka-avacchinna-anuyogy-avacchinna-samsargīyānuyogitāa; 'The relational abstract subjunct-ness $(\boldsymbol{A})$, limited by the subjunct $(a)$, limited by the relational abstract coreferential qualifier-ness $\left(\boldsymbol{V}^{(N)}\right)$ limited by gold-ness $\left(h_{t}\right)$, whose limitor is the relational abstract adjunct-ness $\left(\boldsymbol{A}^{-\boldsymbol{1}}\right)$, limited by the relational adjunct $\left(a^{-1}\right)$, limited by the relational abstract coreferential qualified-ness $\left(\boldsymbol{V}^{(N)-1}\right)$ limited by crown-hood $\left(m_{t}\right)$ in a crown'.

It is thus confirmed that, if [3], then $\left.m . m_{t}\right\urcorner h_{t}$, or mukuṭa-niștha-mukuțatvāvacchinnahätakatvam ('Gold-ness in crown-ness in a crown'). Indeed, if there is a colocated viśeșana, there must be a viśesya on which the former is dependent, lest it not be the qualifier it is. Therefore, gold-ness is revealed to be a colocated conditioned qualifier by virtue of its being conditioned by the domain it qualifies; and crown-ness is a qualified conditioner (or conditioning qualified), imposing the relational reference domain on the colocated qualifier that qualifies it.

SVN can conclude that, in cases of coreferentiality interpreted as a qualifiedqualifier relation ( $N$ as $V$ ), whatever further colocated qualification (viśeșa) be attributed to whatever target of qualification (viśesya), the former must be considered as already bound to the root-property of the latter, the relation reference domain. In other words, since $N$ as $V$ is an instance of closure, its range must be acknowledged 
as a subset of the dominion. Golden crowns are crowns because the relational domain is rooted in the set Crowns. Or rather, if there are golden crowns it is because there is gold-ness in crowns. In other terms, $N$ as $V$ is a mapping of the domain of the qualified (viśeșya) onto the range of colocated qualifiers (viśeșaṇa) and, in so doing, defining a subset of the range which is in turn equal to or a subset of the domain. Consequently, setting aside predication and connective 'and' (' $\wedge$ '), in Nyāya relational account a golden crown is a crown because the set Crowns is the starting and arrival point - a set which stands alone, along with its image under the condition 'gold-property' as a subset of itself. In relation $N$ as $V$ in [3], when talking about goldness we are talking about nothing but crowns. The same holds for blue pots qua pots.

At this juncture, a preliminary account of the notion of coreferentiality has been provided here, relying on the unforeseen and to some extent counterintuitive output of SVN. If that is the case, then it is clear that - being the very same being - a crown and the gold of which it is made cannot actually be said to be different tout court, e.g. the way a crown and a chair are. Nonetheless, it still remains unanswered the question regarding the relational nature of non-difference, and in particular whether this latter might be considered, or rather reduced, to simple cases of equivalence, equality, or identity. The second part of this investigation will be devoted to this issue.

Acknowledgements I would like to express my thanks to Gianni Pellegrini, without whose precious advice this research project would have not been possible.

Funding Open access funding provided by Università degli Studi di Torino within the CRUI-CARE Agreement..

\section{Compliance with ethical standards}

Conflict of interest The author states that there is no conflict of interest.

Open Access This article is licensed under a Creative Commons Attribution 4.0 International License, which permits use, sharing, adaptation, distribution and reproduction in any medium or format, as long as you give appropriate credit to the original author(s) and the source, provide a link to the Creative Commons licence, and indicate if changes were made. The images or other third party material in this article are included in the article's Creative Commons licence, unless indicated otherwise in a credit line to the material. If material is not included in the article's Creative Commons licence and your intended use is not permitted by statutory regulation or exceeds the permitted use, you will need to obtain permission directly from the copyright holder. To view a copy of this licence, visit http://creative commons.org/licenses/by/4.0/.

\section{References}

\section{Sanskrit Texts}

AS-Madhusūdana Sarasvatī (1997) [1937], Advaitasiddhih viț̣aleśīyavyākhyopabṛmhitagauḍabrahmānandīvyākhyāsanāthīkṛtā balabhadrapraṇitasiddhivyākhyā anantakṛṣnaśāstrīsamgṛītanyāyāmṛtādvaitasiddhitaraṃin̄ī laghucandrikāsaṃrahātmakacaturgranthopaskṛtā ca, M.M. Anantakṛṣṇa Śāstrī (ed.). Delhi: Parimal Publication.

Bhartṛhari (1966). Vākyapadīya with the Vrtti and the Paddhati of Vrșabhadeva. Subramania Iyer, K.A. (ed.). Poona: Deccan College Monograph Series. 
Gadādhara Bhaț̣āāāya (1990), Gadādhara's Theory of Objectivity. Part Two. Containing the Text of Gadādhara's Vișayatāvāda with an English Transanslation, Explanatory Notes and a General Introduction. Bhattacharyya S. (ed.). Indian Council of Philosophical Research. Dehli: Motilal Banarsidass.

NK-Jhalakīkar, M.B. (1928). Nyāyakośa or Dictionary of Technical Terms of Indian Philosophy. Poona: Bhandakar Oriental Research Institute.

NSM-Viśvanāthapañcānana Bhațtācārya (1988) [I ed. Madras 1923]. Kārikāvalī muktāvalīsahitā sā ca prabhāmañjūṣādinakarīrāmarudrīgañgārāmīti vyākhyāpañcakasamanvitāa. C. Śankararāma Śāstrī (ed.). Vārāṇasī: Caukhambā Saṃskrta Pratișthāna.

Pāṇini (1999). The Aștāâdhyāȳ̄ of Pāninini. Sharma, R. N. (ed.). Vol. IV. Delhi: Munshiram Manoharlal Publishers Pvt. Ltd.

Śiv. Miśra-Śivadatta Miśra (1928). Gañgā-nīrjhariṇī. In Mathurānātha Tarkavāgīśa, Vyāptipañcakarahasyam and Sinhavyāghralaksanarahasyam, edited with Gaingā-nīrjharin̄i commentary and notes of Sivadatta Misra. Dhundhiraja Sastri (ed.). Kashi Sanskrit Series 64. Benares: Chowkhamba Sanskrit Series.

[Upanișad] (1998). The Early Upanișads. Annotated Text and Translation. Olivelle, P. (ed.). Oxford: Oxford University Press.

VM-B_Brahmasūtraśāmkarabhāṣya with the Commentaries: Bhāṣyaratnaprabhā of Govindānanda, Bhāmatī of Vācaspati Miśra, Nyāyanirnaya of Ānandagiri. Shastri, J.L. (ed.) (2018) [1980]. Delhi: Motilal Banarsidass.

VVR_Bhāskararāya Makhin (1976) [1934]. Varivasyāraharasya and its Autocommentary Prakāśa. S. Subrahmaṇya Śāstrī (ed.), Adyar Library Series n. 28. Madras: Adyar Library.

YH-(1994). Yogin̄̄hṛdaya. Le Cœur de la Yogin̄̄, avec le commentaire Dīpikā d'Amrtānanda. Padoux, A. (ed.). Collège de France, Publications de l'Institut de Civilisation Indienne; 63. Paris: De Boccard.

\section{Other Texts}

Anrò, A. (2019). "Mathematics of a Mantra". Asiatische Studien; https://doi.org/10.1515/asia-2019-0023. Anrò, A. (forthcoming). "Nyāya formalized. Exercises of application". Philosophy East and West.

Bhattacharyya, S. (1987). Some Aspects of the Navya-Nyāya Theory of Inference. Ganeri, 2001, $162-182$. Berge, C. (1963) [1959]. Topological Spaces. Including a Treatment of Multi-Valued Functions, Vector Spaces and Convexity. Trans. by Patterson, E.M. Edinburgh and London: Oliver \& Boyd LTD.

Bilimoria, P. (1985). "Jñāna and Pramā: the Logic of Knowing. A Critical Appraisal". Journal of Indian Philosophy, 13, 1: 73-102.

Bochenski, I.M. (1956). The Indian Variety of Logic; in Ganeri (2001: 117-150).

Bourbaky, N. (1968) [1939]. Elements of Mathematics. Theory of Sets. Paris: Hermann.

Brooks, D. R. (1990). The Secret of the Three Cities: An Introduction to Hindu Śäkta Tantrism. Chicago: University of Chicago Press Ltd.

Brooks, D. R. (1992). Auspicious Wisdom. Texts and Traditions of Śrīvidyā Śākta Tantrism in South India. Albany: State University of New York, SUNY Series in Tantric Studies.

Candotti, M.P. (2005). Interprétations du Discours Métalinguistique. La Fortune du sūtra A $1160 \mathrm{chez}$ Patañjali et Bhartrhari. Florence: Firenze University Press.

Chakraborty, N. B. (1967). The Advaita Concept of Falsity. Calcutta: Sanskrit College.

Dalai, B. K. (1992). Samavāya. In V. N. Jha (Ed.), Relations in Indian Philosophy (pp. 10-28). University of Poona, Centre of Advanced Studies in Sanskrit.

Dasgupta, S. (1933). Indian Idealism. Cambridge: Cambridge University Press.

Dasgupta, S. (1941). Philosophical Essays. Calcutta: University of Calcutta.

Enderton, H. B. (1977). Elements of Set Theory. New York: Academic Press Inc.

Filliozat, P.-S., Grammaire Sankrite Pâninéenne, Paris 1988, Picard.

Fisher, E. (2012). "Just Like Kālidāsa: The Śăkta Intellectuals of Seventeenth-century South India”. The Journal of Hindu Studies; https://doi.org/10.1093/jhs/his021.

Ganeri, J. (2006). Artha. Meaning. Testimony and Theory of Meaning in Indian Philosophical Analysis. New Delhi: Oxford University Press.

Ganeri, J. (2008). Towards a formal regimentation of the Navya-Nyāya technical language I \& II, in M.K. Chakraborty, B. Löwe, M.N. Mitra, S. Sarukkai (eds.), Logic, Navya-Nyāya \& Applications. Homage to Bimal Krishna Matilal. London: College Publications. Studies in Logic 15, 105-12, 123-137. 
Ganeri, J. (2011). The Lost Age of Reason. Philosophy in Early Modern India 1450-1700. Oxford: Oxford University Press.

Goudriaan, T. (1979). In Gupta, S., Goudriaan, T. Hindu Tantrism. Leiden-Köln: E. J. Brill.

Goudriaan, T./Gupta, S. (1981). Hindu Tantric and Śākta Literature. In Gonda, J. (ed.), History of Indian Literature. Wiesbaden: Harrassowitz, Vol. II, fasc. 2.

Halmos, P. R. (1960). Naive Set Theory. New York: Van Nostrand Reinhold Company.

Ingalls, D. H. H. (1951). Materials For the Study of Navya-Nyāya Logic. Delhi: Motilal Banarsidass.

Jech, T. (2006) [1978]. Set Theory. The Third Millenium Edition, revised and expanded, corrected 4th printing, Berlin, Spinger.

Jha, V. N. (2001). Dictionary of Nyāya Terms. University of Pune, Centre of Advanced Studies in Sanskrit. Levy, A. (2002) [1979]. Basic Set Theory. Mineola, N.Y.: Dover Publications Inc.

Loux, M. J., (2005) [1998]. Metaphysics. A contemporary Introduction [Trd. ed.]. New York and London: Routledge.

Ludlow, P. (2018). "Descriptions". The Stanford Encyclopedia of Philosophy (Fall Edition), Edward N. Zalta (ed.), URL: <https://plato.stanford.edu/archives/fall2018/entries/descriptions/>.

Matilal, B. K. (1968). The Navya-Nyāya Doctrine of Negation. The Semantic and Ontology of Negative Statements in Navya-Nyāya Philosophy. Cambridge, Massachusetts: Harvard University Press.

Matilal, B.K. (1998). Introducing Indian Logic. In Ganeri 2001-b: 183-215.

Moschovakis, Y. (2006). Notes on Set Theory. New York: Springer.

Pellegrini, G. (2013: 43-81). In: Gabin, J.-L., Pellegrini, G., eds. (2013). Symboles du monothéisme hindou. Paris: Les Éditions du Cerf.

Pellegrini, G. (2014). 'Is There Any Need for Doubt?: The Incipit of Advaitasiddhi'. In Nagoya Studies in Indian Culture and Buddhism, Special Issues for Papers Presented at the 15th World Sanskrit Conference edited by Kamaleswar Bhattacarya, Sambhāṣā, vol. 31, 3-19.

Phillips, S.H. (1997). Classical Indian Metaphysics. Refutation of Realism and the Emergence of 'New Logic'. Delhi: Motilal Banarsidass.

Potter, K. (1954). Book Review: 'Materials for the Study of Navya-Nyāya Logic' by Daniel Henry Holmes Ingalls. Philosophy East and West, 4(3), 271-272.

Potter, K. H. (1981). Advaita Vedanta up to Samkara and His Pupils. The Encyclopedia of Indian Philosophies. Vol. III. Delhi: Motilal Banarsidass.

Potter, K. H. (2002) [1991]. Presupposition of India's Philosophies. Delhi: Motilal Banarsidass.

Priest, G. (2000). Logic. A Very Short Introduction. New York: Oxford University Press Inc.

Quine, W. V. O. (1960). World and Object. Cambridge: MIT Press.

Quine, W.V.O. (1981). Mathematical Logic. Revised edition. Cambridge, Massachusetts: Harvard University Press.

Rai, A. K. (1995). Pakșatā in Navya-Nyāya. Journal of Indian Philosophy, 23(1), 1-8.

Ram-Prasad, C. (2002). Advaita Epistemology and Metaphysics: An Outline of Indian Non-Realism. London: Routledge Curzon.

Renou, L. (1957). Terminologie grammaticale du Sanskrit. Vol. I. Bibliothèque de 1'Ecole des hautes études n. 280. Paris: Honoré Champion Editeur.

Russell, B. (1919). Introduction to Mathematical Philosophy. London: George Allen and Unwin.

Sanderson, A. (1988). Śaivism and the Tantric Tradition. In S. Sutherland, et al. (Eds.), The World's Religions (pp. 660-704). London: Routledge.

Sanderson, A. (2014). "The Śaiva Literature". Journal of Indological Studies (Kyoto) Nos. 24 \& 25 (2012-2013): 1-113.

Schmidt, G. (2011). Relational Mathematics. Cambridge: Cambridge University Press.

Shaw, J. L. (1976). Subject and Predicate. Journal of Indian Philosophy, 4(1/2), 155-179.

Shaw, J. L. (1989). Saturated and Unsaturated: Frege and the Nyāya. Synthese, 80(3), 373-394.

Shaw, J. L. (2010). Navya-Nyāya on Subject-Predicate and Related Pairs. Journal of Indian Philosophy, 38(6), 625-642.

Sihna, J. (1934), Indian Psychology. Perception. London: Kegan, Trench, Trubner \& Co. Ltd.

Smullyan, R. M., \& Fitting, M. (1996). Set Theory and the Continuum Problem. Oxford: Clarendon Press.

Staal, F. (1960). Book Review: D.H.H. Ingalls, 'Materials for the Study of Navya-Nyāya Logic'. IndoIranian Journal, 4, 1: 68-73.

Staal, F. (1973). The Concept of Pakșa in Indian Logic. In Ganeri (2001: 151-160).

Staal, F. (1988). Universals. Studies in Indian Logic and Linguistics. Chicago and London: The University of Chicago Press.

Strawson, (1974). Subject and Predicate in Logic and Grammar. London: Methuen. 
Timalsina, S. (2006). Seeing and Appearance. Aachen: Shaker Verlag.

Timalsina, S. (2009). Consciousness in Indian Philosophy. The Advaita doctrine of 'awareness only'. London \& New York: Routledge.

Publisher's Note Springer Nature remains neutral with regard to jurisdictional claims in published maps and institutional affiliations. 